UNIVERSIDADE DA BEIRA INTERIOR

Ciências da Saúde

\title{
Serum Biomarkers in Elderly Asthma
}

\author{
João Pedro Cavaleiro Rufo \\ Dissertação para obtenção do Grau de Mestre em \\ Ciências Biomédicas \\ ( $2^{\circ}$ ciclo de estudos)
}

Orientador: Prof. Doutora Olga Lourenço

Covilhã, Junho de 2013 
Serum Biomarkers in Elderly Asthma 
Serum Biomarkers in Elderly Asthma

"Victoria discentium, gloria docentium" 


\section{Acknowledgements}

À minha orientadora, a Professora Doutora Olga Lourenço, um profundo agradecimento por toda a orientação, dedicação, e paciência que para comigo demonstrou, nos bons e nos maus momentos. Um grande obrigado por todos os segredos de citometria que comigo partilhou, permitindo-me ver e compreender aquilo que realmente podemos encontrar na folha de aquisição, para além de pontos e eixos em fundo branco.

Ao Professor Doutor Luís Taborda Barata, por toda a ajuda que forneceu para a submissão do nosso artigo, e por ter estimulado o meu interesse nesta área da Alergologia.

À Professora Doutora Mafalda Fonseca pela fundamental transmissão de conhecimentos de imunologia e pelas pequenas mas valiosas sugestões sobre citometria de fluxo.

À minha família, em especial aos meus pais, por toda a preocupação e ajuda que disponibilizaram. Sem eles nunca teria conseguido chegar onde cheguei.

Ao David e ao Paulo, por terem partilhado comigo, durante cinco anos, os bons momentos da vida e do espírito académico, contribuindo de igual parte para a coleção de boas memórias que adornam o topo dos armários da nossa cozinha.

À Laura, pelo seu sempre presente espírito crítico, por rever este manuscrito e dar a sua opinião imparcial, como se da sua própria dissertação se tratasse, e pela ajuda que me deu nos momentos mais difíceis do último ano.

A todos os amigos e colegas com os quais partilhei a magia da Covilhã no decorrer desta importante fase da minha vida. Foram uma verdadeira família.

Ao Gonçalo Nogueira, pela ajuda que me deu com a chave dos questionários que contribuíram para a seleção dos voluntários deste estudo.

À Doutora Graça e Doutora Patrícia por me terem feito sentir "em casa" no Laboratório de Patologia Clínica, no Hospital da Guarda, e por todas as instruções que tornaram tão fácil operar o ImmunoCAP250 ${ }^{\mathrm{T}}$.

À Fundação para a Ciência e Tecnologia pelo financiamento deste estudo (PTDCU/ESA/100666/2008 - FCT). 
Serum Biomarkers in Elderly Asthma 


\section{Resumo Alargado}

A asma é uma doença crónica das vias aéreas que afeta todas as idades e é incorretamente tratada ou sub-diagnosticada na população idosa, resultando em complicações para o doente e numa diminuição da qualidade de vida. Diferentes fenótipos podem requerer diferentes tratamentos e, portanto, é necessário diagnosticar corretamente qual o tipo de asma de que o doente sofre. Apesar de grande parte do tratamento e pesquisa se concentrarem na asma alérgica, existem várias outras formas da doença que requerem atenção, tal como a asma neutrofílica ou asma não-alérgica, que afeta normalmente os doentes mais velhos. A doença pulmonar obstrutiva crónica (DPOC), também muito comum em idosos, pode prejudicar ainda mais o diagnóstico da asma, devido às semelhanças entre as duas doenças. Biomarcadores da asma estão a ser estudados clinicamente com vista a aumentar o poder discriminativo entre os diferentes fenótipos da doença, estando as citocinas dentro dos mais promissores.

Assim sendo, o nosso principal objetivo foi medir seis citocinas, nomeadamente a IL-1B, IL-6, IL-8, IL-10, IL-12p70 e TNF-a, no sangue periférico de uma população de idosos asmáticos. Pretendíamos também usar a citometria de fluxo para quantificar as citocinas, de modo a podermos comparar facilmente os resultados e estabelecer padrões citocínicos. Também tínhamos como objectivo avaliar alterações nos padrões citocínicos relacionadas com a idade, usando um grupo controlo de adultos jovens. Por fim, pretendíamos investigar possíveis alterações nos padrões citocínicos relacionados com cada fenótipo da asma (alérgica ou não-alérgica).

A população deste estudo foi constituída por 16 idosos com asma alérgica, 20 idosos com asma não-alérgica, 9 idosos não asmáticos para controlo, assim como 11 adultos jovens não asmáticos para controlo, recrutados através de uma base de dados. Os indivíduos foram inseridos nos respectivos grupos pelos resultados de testes cutâneos, medição da IgE total e específica, e pelas respostas dadas a um questionário. As citocinas previamente referidas foram quantificadas no soro dos indivíduos por citometria de fluxo, usando o Cytometric Bead Array (CBA) Human Inflammatory Cytokines Kit (BD Biosciences).

Os resultados obtidos mostraram que o TNF-a, a IL-10 e a IL-8 se encontravam elevadas no grupo dos asmáticos não alérgicos, apesar da diferença não ser significativa. A IL-6 encontrava-se significativamente elevada no grupo dos idosos com asma não-alérgica, quando comparada com ambos os grupos de controlo e quando comparada com o grupo dos adultos jovens individualmente, embora não tenham sido encontradas diferenças significativas quando comparada com o grupo de controlo dos idosos, separadamente. Os níveis de IL-1B encontravam-se elevados no grupo dos adultos jovens, porém sem significado estatístico. A IL8 encontrava-se geralmente mais elevada nos idosos. A IL12p70 não foi detectada em nenhum indivíduo. 
Concluindo, medimos as citocinas previamente referidas no sangue periférico de uma população idosa, cumprindo assim o nosso objectivo principal. Porém, não foi possível definir um padrão de altercações a nível das citocinas relacionado com diferenças entre os fenótipos ou relacionadas com o envelhecimento, embora tenha sido possível notar uma tendência para um aumento das citocinas ligadas à severidade (TNF-a, IL-6 e IL-8) no grupo dos idosos com asma não-alérgica, o que nos leva a concluir que este fenótipo da asma é, de facto, mais severo, tal como sugere a bibliografia.

o principal ponto forte é o facto deste ser o primeiro estudo a medir estas seis citocinas no soro de idosos com asma. Uma limitação deste estudo centra-se no facto dos voluntários terem sido classificados como asmáticos através das respostas a um questionário, não tendo, portanto, nenhuma confirmação clínica da existência da patologia. Isto pode ter levado à inclusão de voluntários nos grupos errados.

Para obtenção de melhores resultados os voluntários deveriam ser recrutados após o diagnóstico efetuado por um especialista e submetidos a testes complementares, como por exemplo a espirometria, de modo a garantir a correta inserção dos indivíduos nos grupos. Outros dos marcadores referenciados neste trabalho, como a proteína catiónica dos eosinófilos (ECP) e a YKL-40, também aparentam ter algum potencial para a monitorização e diagnóstico da asma, devendo ser investigados.

\section{Palavras-chave}

Asma; Biomarcadores; Citocinas; Citometria de fluxo; Diagnóstico; Idosos. 
Serum Biomarkers in Elderly Asthma 


\section{Abstract}

Asthma is a chronic disease of the airways that can affect all ages. It is usually undertreated in the elderly population, resulting in complications and increased severity for the patient. Different phenotypes may imply different treatments and therefore it becomes important to correctly determine which type of asthma the patient is suffering from. Biomarkers of asthma have been clinically studied in order to help discriminate among the different phenotypes of the disease, cytokines being among the most promising. Our main goal was to measure six serum cytokines, including IL-1B, IL-6, IL-8, IL-10, IL-12p70 and TNFa, in an elderly population with asthma.

The population of this study included 16 elderly patients with allergic asthma, 20 elderly patients with non-allergic asthma, 9 elderly control individuals, as well as 11 young adult control individuals. The serum of the experimental subjects was quantified for the six aforementioned cytokines by flow cytometry, using the Cytometric Bead Array (CBA) Human Inflammatory Cytokines Kit (BD Biosciences).

The results showed that the measured levels of TNF- $a$, IL-10 and IL- 8 were increased in the non-allergic asthmatics group, although with no statistical significance. IL-6 was significantly increased in the elderly non-allergic asthmatic group, when compared to both control groups and when compared to the young adult controls alone, but no significant differences were found when comparing to the elderly control group separately. IL-1B median levels were shown to be elevated in the young adults control group, but also without a significant statistical difference. IL-12p70 was not detected in any subject.

In conclusion, we could not define a pattern of changes in the measured cytokine levels related to phenotype differences or aging, although it is possible to notice a trend for increased levels of severity cytokines (TNF-a, IL-6 and IL-8) in non-allergic asthmatic elderly individuals, suggesting that this phenotype of asthma is indeed more severe than its counterpart. So far, this is the only study that measured the aforementioned serum inflammatory cytokines in an elderly population with asthma.

\section{Keywords}

Asthma; Biomarkers; Cytokines; Diagnosis; Elderly; Flow cytometry. 
Serum Biomarkers in Elderly Asthma 


\section{Table of Contents}

$\begin{array}{ll}\text { Chapter } 1 \text { - Introduction } & 1\end{array}$

1.1 Asthma Physiopathology 1

1.2 Distinguishing Asthma from COPD 3

1.3 Asthma in Elderly Patients 3

1.4 Serum Biomarkers for Asthma 4

$\begin{array}{ll}1.5 \text { Cytokines } & 10\end{array}$

1.6 The need for new markers 13

$\begin{array}{ll}1.7 \text { Objectives of the study } & 14\end{array}$

Chapter 2 - Materials and Methods 16

$\begin{array}{ll}\text { 2.1 Study Design } & 16\end{array}$

$\begin{array}{ll}2.2 \text { Population Selection } & 16\end{array}$

$\begin{array}{ll}2.3 \text { Quantification of Cytokines } & 17\end{array}$

$\begin{array}{ll}2.4 \text { Statistical Analysis } & 17\end{array}$

Chapter 3 - Results $\quad 19$

$\begin{array}{ll}3.1 \text { Study Population } & 19\end{array}$

$\begin{array}{ll}3.2 \text { Flow Cytometry } & 20\end{array}$

Chapter 4 - Discussion and Conclusions $\quad 25$

$\begin{array}{lr}\text { 4.1 Future Prospects } & 27\end{array}$

Chapter 5 - Bibliography $\quad 28$

$\begin{array}{ll}\text { Attachments } & 35\end{array}$ 


\section{List of Figures}

Figure 1 - Flow-chart of the methodology used for group selection.

Figure 2 - Example of two acquisition cases.

Figure 3 - Box plot of the measured concentrations of IL-8, sorted by groups.

Figure 4 - Box plot of the measured concentrations of IL-1B, sorted by groups.

Figure 5 - Box plot of the measured concentrations of IL-6, sorted by groups.

Figure 6 - Box plot of the measured concentrations of IL-10, sorted by groups.

Figure 7 - Box plot of the measured concentrations of TNF-a, sorted by groups.

Figure 8 - Calibration curve for IL-12p70.

Figure 9 - Calibration curve for TNF-a.

Figure 10 - Calibration curve for IL-10.

Figure 11 - Calibration curve for IL-10.

Figure 12 - Calibration curve for IL-1B.

Figure 13 - Calibration curve for IL-8. 


\section{List of Tables}

Table 1 - Characterization of the study population.

Table 2 - Median [max; min] levels of the studied cytokines, sorted by groups.

Table 3 - Summary of studies evaluating serum biomarkers of asthma.

Table 4 - Summary of studies evaluating serum cytokines as markers of asthma.

Table 5 - Fluorescence values for standard concentrations of IL-12p70. MFI values at $625 \mathrm{pg} / \mathrm{ml}$ were out of the normal range of the curve.

Table 6 - Fluorescence values for standard concentrations of TNF-a.

Table 7 - Fluorescence values for standard concentrations of IL-10.

Table 8 - Fluorescence values for standard concentrations of IL-6

Table 9 - Fluorescence values for standard concentrations of IL-1B.

Table 10 - Fluorescence values for standard concentrations of IL-8. 


\title{
List of Acronyms
}

\author{
AA - Allergic asthmatics \\ $A C$ - Young adult controls \\ APC - Antigen presenting cells \\ APP - Acute phase protein \\ AT - After treatment \\ BAL - Bronchoalveolar lavage \\ BT - Before treatment \\ CBA - Cytometric bead array \\ COPD - Chronic obstructive pulmonary disease \\ CRP - $C$ reactive protein \\ $\mathrm{EAACl}$ - European Academy of Allergology and Clinical Immunology \\ EC - Elderly controls \\ ECP - Eosinophils cationic protein \\ ELISA - Enzyme linked immunosorbent assay \\ Fas - Cell death receptor \\ FceRI - High affinity receptor I \\ FeNO - Fractionally exhaled nitric oxide \\ FEV1 - Forced expiratory volume at the first second \\ $\mathrm{HC}$ - Healthy controls \\ HIV - Human immunodeficiency virus \\ Hs-CRP - Highly sensitive C reactive protein \\ ICS - Immunocorticosteroid \\ IgE - Immunoglobulin E \\ ISAAC - International Study of Asthma and Allergies in Childhood \\ MMP - Membrane-type metalloproteinase \\ MSD - Meso Scale Discovery \\ NA - Neutrophilic asthmatics \\ NAA - Non-allergic asthmatics \\ NNA - Non-neutrophilic asthmatics \\ OAD - Obstructive airways disease \\ PBE - Peripheral blood eosinophils \\ RD - Respiratory diseases \\ SAA - Serum amyloid A \\ sCD86 - Soluble CD86 \\ slgE - Specific IgE
}


SPT - Skin prick tests

tlgE - Total lgE

Treg - T regulatory lymphocytes

UTI - Urinary trypsin inhibitor 
Serum Biomarkers in Elderly Asthma 


\section{Serum Biomarkers in Elderly Asthma}




\section{Chapter 1}

\section{Introduction}

\subsection{Asthma Physiopathology}

Asthma is a chronic inflammatory disorder of the airways, leading to episodic shortness of breath, cough and wheezing, particularly in the night or early morning. The main physiological feature of asthma consists in episodic bronchial obstruction, which is often reversible, whereas the pathological feature is airways inflammation, including possible structural changes of the affected organs (1). Airways epithelial cells largely express chemokines, recruiting leukocytes to participate in this inflammatory process. These cells will release cytokines which will trigger a mainly Th2 immune response, increasing eosinophilia and histamine production by mast cells, among other defence mechanisms.

A subject who suffers from asthma is generally hypersensitive to certain allergens, causing an abnormal IgE-mediated immune response. Eosinophils, mast cells, neutrophils, T helper cells and dendritic cells participate in this acute inflammation (2). Dendritic cells are the main antigen-presenting cells (APCs) in the immune reaction, activating mast cells through IgE attached to their high affinity receptors ( $F \subset \varepsilon R I)$, degranulating and releasing inflammatory components, such as histamine, which is known to be a bronchoconstrictor ( 3 , 4). Allergens will also be presented to CD4+ $T$ helper cells. In asthma, the activated $T$ cells will produce a Th2 characteristic response (5), releasing IL-4 and IL-5 (among other cytokines) that will participate in the inflammation and contribute to a late chronic response (2). IL-4 will raise IgE production by $B$ cells, while IL-5 will raise eosinophilia in affected areas. Eosinophils will also produce IL-4, further increasing IgE production. The produced IgE is released into serum and finally attaches to FcعRI receptors on mast cells, causing their degranulation and anaphylactic responses when the subject contacts with the same allergen (6).

Certain phenotypes of asthma consist in a Th1 cytokine-mediated rather than a typical Th2 response (7). Neutrophils and macrophages are characteristic of Th1 inflammatory responses. Neutrophilia is increased in patients with severe asthma and in smoking asthmatics, although it is suspected to be caused by corticosteroid therapy (1). Neutrophils seem to be recruited by IL-8 $(8,9)$.

Recent advances in both immunological and clinical phenotyping of asthma have raised the possibility that Th17 cells may trigger the pathology or co-exist with a Th2 type inflammation (10). Th17 cells are T helper lymphocytes that produce elevated levels of IL-17. 
A recent study found increased numbers of Th17 cells in allergic patients, compared to nonallergic, and further showed that IL-17 could also induce class switching to IgE in human B cells, suggesting a more direct mechanism for Th17 induced atopic phenotypes $(11,12)$. Further studies in human patients have demonstrated that Th17 cells may also have a role in asthma pathogenesis by promoting airway smooth muscle cell migration, consequently leading to airway remodelling and possible airway narrowing $(11,13)$. Further proof was found using mice models, where IL-22 produced by Th17 cells also appears to have part in induction of experimental asthma, as well as suppressing the established disease $(13,14)$. While there is evidence about Th17 cells playing a role in asthma and atopic disease, their inflammatory mechanisms are still unclear and need further study. However, association between IL-17 and asthma is established and the possibility to use this cytokine as a marker for asthma exacerbations is being studied $(15,16)$.

T regulatory lymphocytes (Treg) are necessary to control the inflammatory response against allergens, releasing imunosuppressor cytokines or inducing anergy in other inflammatory cells. Tregs are known to be decreased in patients with asthma and other allergic diseases and are not as effective in suppressing allergen-stimulated effector T cells, which will consequently result in higher IL-4 serum levels and a more severe Th2 response (17).

Airway narrowing is the final common pathway leading to symptoms and physiological changes in asthma. It is caused by airway smooth muscle contraction in response to bronchoconstrictor mediators and neurotransmitters $(18,19)$. This occurrence is normally reversible by administration of bronchodilators. Inflammation may also produce mediators that will increase microvascular leakage and cause airway edema, especially during acute exacerbations. Furthermore, as asthma's severity intensifies, airway remodelling will also intensify, resulting in structural changes that may cause airway thickening. This is not fully reversible by current therapy $(18,20)$.

The characteristic abnormality in asthma is the airway hyperresponsiveness which may lead to one or more of the airway narrowing mechanisms mentioned above. It is caused by a stimulus that would normally be innocuous in a normal person, resulting in an anaphylactic response. However, airway narrowing in asthma is not exclusively caused by hyperresponsiveness to allergens. Acute asthmatic exacerbations may occur when exposure to certain conditions are met, also called "triggers", such as exercise, weather conditions or air pollutants $(21,22)$. Also, asthma tends to worsen at night. This is called nocturnal asthma and its triggers are not fully understood, but a night-time reduction in endogenous antiinflammatory mechanisms is suspected to be the cause $(1,23)$.

External and temporal factors are not the only reasons for asthma exacerbations and worsening. Different phenotypes of asthma may be more difficult-to-treat, which is the case of neutrophilic asthma, severe and unresponsive to corticosteroids, with more structural changes (24). This type of asthma is generally non-allergic with a rather weak Th2 response 
when compared to other phenotypes of the disease, but with an increased Th1 inflammatory response. It is characteristic of older patients with a late onset of asthma and it usually starts in a severe form rather than progressing from a mild/moderate form (25). Asthmatic smokers may also tend to have a more neutrophilic asthma (26).

\subsection{Distinguishing Asthma from COPD}

Both asthma and chronic obstructive pulmonary disease (COPD) are major chronic obstructive airways disease (OAD) that involve underlying airway inflammation and may be difficult to differentiate (1). Unlike asthma, COPD airflow limitation is not fully reversible and is usually progressive, but these symptoms may be hard to distinguish from asthma's, especially when concerning elderly and smoking asthmatics (27). It was observed that asthmatic patients had more allergic sensitivity, greater eosinophilia in peripheral blood, bronchoalveolar lavage (BAL) and sputum, higher levels of serum IgE, greater increases in FEV1 after treatment with corticosteroids, and less common smoking history, when compared to COPD patients $(28,29)$. However, the levels of some markers can still overlap making it harder to diagnose. Tinkelmen et al (2006) developed a questionnaire for differentiating asthma from COPD (27). Despite being an easy and economic diagnostic method, its accuracy is questionable because the patient may not be so sure of his symptoms, among other limitations $(27,30)$, and it should only be used as a supplementary diagnostic tool.

\subsection{Asthma in Elderly Patients}

Asthma can affect all ages and it is often misdiagnosed, under diagnosed and undertreated in elderly patients (31). There is an estimated proportion of $6.5-17 \%$ sufferers of asthma in this age group, and deaths resulting from it occur mostly among these patients (32). This mortality rate is often associated with poor diagnosis and inadequate treatment. The complexity of the disease, with variable clusters of phenotypes and endotypes along with symptoms similar to those of other OAD and possible comorbidities are the principal obstacles to the diagnosis of asthma (31-34). In addition, lung capacity of individuals over 65 years of age tends to decrease by about $40 \%$ over time (35). This loss of lung function may compromise diagnostic tests, as it produces a characteristic change in the flow-volume curve which is typical of small airways disease (34). In addition, eosinophils may have an altered or decreased role in airway inflammation in elderly asthmatic patients (28), thereby leading to an increase in airways neutrophilia. Furthermore, different phenotypes of asthma may be more difficult to treat, more severe and unresponsive to corticosteroids, showing more extensive structural changes (24).

Although several distinct forms of asthma are recognised, the major focus of treatment and research has been on allergic asthma (36). This phenotype of asthma is characterised by the presence in the lungs of asthmatic patients of allergen-specific Th2 cells (37), that produce cytokines such as IL-4, IL-5, IL-9 and IL-13. Another characteristic of allergic asthma 
is the abnormally high levels of serum allergen-specific IgE possibly due to the action of augmented IL-4 production, as well as a significant enhancement in eosinophilia in serum and bronchial mucosa, most likely due to the effects of increased IL-5 production (38).

Non-allergic asthma is a less common phenotype as it accounts for two out of every five cases of asthma in adults and constitutes both in terms of symptoms and lung function, a more severe form of the disease (39). This form of asthma tends to be more frequently associated with higher numbers of serum and sputum neutrophils and is characteristic of older patients with a late onset of the disease, with reduced response to corticosteroids and it usually has a more severe and abrupt onset rather than progressing from a mild to a moderate form $(24,25)$. In addition, asthmatic smokers also tend to develop neutrophilic asthma (26). This more neutrophilic cellular phenotype of asthma is characterized by a less apparent Th2type response when compared to other phenotypes, and tends to be more frequently associated with an increased Th1-type inflammatory response. This increment in a Th1-type response may be correlated with the increased neutrophilia, since IL8-mediated neutrophil influx is typically associated with activation of the innate immune system, thereby suggesting that neutrophilic asthma may be involved in its activation $(9,40,41)$.

Elderly patients with non-allergic asthma may have low serum lgE levels as a consequence of immunosenescence, thus making it even harder to diagnose (42).

Apoptosis is an important procedure to depurate dysfunctional cells. As the aging process goes on, cells become more sensitive to apoptosis with an increased expression of the death receptor Fas (also called CD95), helping to keep tissue homeostasis $(34,43)$. Todo-Bom et al (44) analyzed the expression of CD95 in elderly asthmatics and compared its values with the expression of the same marker on healthy elderly controls, suspecting a decreased sensitivity to apoptosis in asthmatics. The different was non-significant, which could be caused by the Fas system reduced activity in Th2 environment, or simply because there is no relation between asthma and changes in apoptosis sensitivity (45). Concluding, apoptosis sensitivity is raised in elderly patients, which is represented by an increase in CD95 expression. Apoptosis is probably reduced in elderly asthmatics not treated with steroids, although there is no significant evidence of that incidence.

\subsection{Serum Biomarkers for Asthma}

Many biomarkers of asthma have been clinically studied in order to determine their diagnostic value and several are currently being used by physicians to identify the phenotype of asthma affecting their patients, thereby assisting in the choice of the most appropriate treatment. Biomarkers for asthma can be found in serum, sputum, bronchial alveolar lavage (BAL) and bronchial biopsies. Bronchial biopsies and BAL have the highest diagnostic value for asthma. However, they require extremely invasive and complicated techniques, thus becoming hard to use as a routine diagnostic tool. Fractionally Exhaled Nitric Oxide (FeNO), 
on the other hand, is a less invasive assay that measures the exhaled nitric oxide, thereby indirectly assessing the level of inflammation in the airways. Nevertheless, the level of diagnosis based upon FeNO decreases in patients with smoking habits or other OAD $(46,47)$. Serum biomarkers are easily assessable and can be easily quantified, needing only blood samples to be retrieved from the patients.

In the next section we describe several clinical research studies based on various serum markers and their relevance to the diagnosis and/or monitorisation of asthma in elderly patients.

$\lg \mathrm{E}$

Atopic patients over express IgE, namely to common allergens, which makes them more prone to developing allergic diseases. In this regard, IgE may be a crucial factor underlying airway hyperresponsiveness in asthma. Measurement of serum total IgE (tlgE) was one of the first tests used to the study of allergic inflammation and it was thought to be a good and easily measurable marker of asthma, since asthmatic patients tended to be allergic (48). However, this was proven to be not necessarily true. It may help to exclude a diagnosis of COPD since the inflammatory response in this disease is associated with a lower concentration of serum IgE when compared with asthma (49), but despite the good sensitivity, total serum IgE has a poor specificity and negative predictive value as other diseases may also have increased IgE levels. This is the case of patients with helminthiases or other allergic diseases, such as allergic dermatitis (50-53). In addition, in elderly patients, serum tlgE levels are generally lower than in younger adults, which may decrease the sensibility of this test. Overall, determination of tlgE levels in elderly asthmatic patients has to be interpreted with caution.

In contrast, the quantification of allergen-specific IgE (slgE) may be clinically relevant to the diagnosis of allergic diseases. It measures the circulating levels of IgE in response to a specific allergen. This can be quantified through an IgE auto-analyzer, such as Phadia $\circledast$ (ImmunoCAP), which measures the response of slgE to specific allergens, thus determining the atopic status of a patient. If the test results are greater than $0.35 \mathrm{PAU} / \mathrm{L}$ the patient can be regarded as atopic. Phadiatop (ImmunoCAP) and food allergy screening panels (such as fx 5 for common childhood food allergens, also for ImmunoCAP) are recommended as the IgE antibody analyses for asthma clinical trials (54). In addition, slgE may be indirectly measured in the skin using skin prick tests (SPT). SPT measures mast cells degranulation on the skin in response to certain allergens, thus obliquely quantifying the slgE for that allergen. The SPT method has a great diagnostic value, but the lack of full standardization, plus adverse skin topography in certain patients, reduces its value in clinical research $(54,55)$. An asthmatic patient can be regarded as atopic when there is positive hyperresponsiveness to at least one allergen, in a SPT (when an edema with at least $3 \mathrm{~mm}$ in diameter is formed). King et al (2004) performed a study in elderly asthmatics (33 asthmatics, 21 healthy controls), showing that among five slgE to cat, ragweed, German cockroach, Dermatophagoides pteronyssinus 
and oak allergens, only lgE for Dermatophagoides pteronyssinus was significantly higher in asthmatic than in non-asthmatic patients (56).

Due to the different aspects of SPT and slgE quantification, both tests are recommended as diagnostic tools for detecting asthma and atopy.

\section{CRP and Hs-CRP}

Acute phase proteins (APP) tend to be elevated in the serum of patients suffering from infections or other inflammatory conditions (57). C reactive protein (CRP), which is one of the most studied and easily measurable positive APP, is known to be over expressed in the presence of systemic inflammation. Since asthma is regarded as an inflammatory disease of the airways, Buyukozturk et al (2004) tested CRP as a potential marker of asthmatic inflammation, in a population of 50 adult patients with rhinitis, 20 adult asthmatics and 20 healthy controls with matching age. These authors concluded that the mean CRP levels of patients with asthma and rhinitis were not significantly different from those of healthy control groups (58). Furthermore, results obtained by Bafadhel et al (2006) showed that CRP levels did not significantly discriminate between patients with asthma and COPD (59). This study was composed of 96 adult asthmatics, 62 adult patients with pneumonia, and 161 adult patients with COPD exacerbations.

However, different results were obtained when the same marker was tested using highly sensitive CRP (hs-CRP) determination. Hs-CRP test essentially quantifies the same marker but is able to detect very small amounts of the protein in serum $(0.5$ to $10 \mathrm{mg} / \mathrm{L})$, whereas normal CRP quantification is only able to measure in the range from 10 to 1000 $\mathrm{mg} / \mathrm{L}$. In a study comprising 24 corticosteroid naive adult asthmatics, 26 adult asthmatics treated with corticosteroids and 15 healthy controls of similar age, Allam et al (2009) showed that hs-CRP is significantly increased in patients with asthma, even in those treated with corticosteroids, when compared to healthy controls (60). Another interesting study involving hs-CRP was performed by Wood et al (2012), showing that hs-CRP is not significantly elevated in every asthma phenotype but only in neutrophilic asthma, which is characteristically more severe, with increased systemic inflammation (7). 106 adult non-neutrophilic asthmatics, 26 adult neutrophilic asthmatics and 83 adult controls participated in this study. With these results in mind, and in face of the simplicity and accessibility of the test, hs-CRP could be a possible serum marker for further supporting a clinical diagnosis of asthma since it can indirectly detect the degree and phenotype of airways inflammation. However, this data has still to be interpreted with caution since another study, by Tilemann et al (2007), contradicted these results by showing that hs-CRP levels in asthmatic patients were not significantly different from subjects with no OAD, thus suggesting hs-CRP may only be accurate for a diagnosis of COPD (49). The population of this study consisted in 86 adult asthmatics, 36 adult patients with COPD, 15 adult patients with partial reversibility of airways alteration, and 75 healthy adult controls. 
Altogether, hs-CRP appears to be much more clinically reliable as a marker of asthma than ordinary CRP measurement.

\section{Urinary Trypsin Inhibitor}

As discussed before, elderly asthma is characteristically more neutrophilic, which suggests that there may be increased neutrophil activity in the inflammatory process. As such, monitoring neutrophilic activity may be a good way to support a diagnosis of asthma in the elderly. In this regard, Yasui et al (2003) studied serum urinary trypsin inhibitor (UTI) in 25 asthmatic children and 15 healthy controls of matching age and showed that UTI levels were significantly greater in asthmatic children (61). These authors further suggested that serum UTI, a metabolite released by neutrophil elastase, might correlate with the patient neutrophils blood count, thus being useful for evaluating the neutrophil-mediated inflammation in childhood asthma (61). However, in spite of the good results obtained, little is known about the accuracy of UTI as a marker for asthma exacerbations since this is the only study available, to our knowledge. In addition, this study was carried out in children and the relevance of UTI levels have not yet been studied in elderly asthmatic patients.

\section{Eosinophil Cationic Protein}

Eosinophils are known to play an important role in inflammation in asthma, with increased numbers of this cell type having been reported in peripheral blood and airway secretions in asthmatic patients (for review see (62)). One of the eosinophil granule proteins, eosinophil cationic protein (ECP), has been widely characterized and researched as a marker of asthma $(24,63)$. In a study involving 441 adult patients with respiratory diseases and 33 healthy adult controls, Peona et al (2010) showed that ECP was significantly higher in the affected group, compared with healthy volunteers, particularly in female patients (64). In addition, the significantly high ECP levels in asthma compared to other respiratory diseases led the authors to suggest that serum ECP may be considered a marker for identifying patients with isolated asthma with an efficiency of $73 \%$, despite not being useful for the discrimination of other respiratory disorders. However, the authors did not find any correlation between serum ECP and the absolute numbers of peripheral blood eosinophils. Studying 17 adult asthmatics before treatment with inhaled steroids, 10 adult asthmatics treated with inhaled steroids and 10 healthy adult controls, Ozseker et al (2006) found similar results in asthmatic patients not treated with inhaled steroids and further showed that there is no significant difference in the expression of ECP between healthy subjects and asthmatic patients treated with inhaled steroids (65). These findings support the theory that eosinophilic asthma is normally responsive to corticosteroids and that ECP may be a good marker for distinguishing eosinophilic asthma from other OAD and other asthma phenotypes. Yet, King et al (2004) showed that ECP levels were not significantly different between asthmatic and non-asthmatic patients in the elderly population, suggesting that ECP is elevated in the elderly population but is not related with asthma, classifying it as a potential 
and simple test for differentiating between the allergic and non-allergic phenotypes (56). These results could compromise the usefulness of serum ECP as a marker for eosinophilic asthma in elderly. In a similar line of results, Koh et al (2006) state in their review that ECP correlates well with airway inflammation but not with airway hyper-responsiveness and it is increased not only in asthma but also in other atopic diseases, thus not being a good marker for the diagnosis of asthma (66). Nevertheless, results may support ECP as a guide to tailoring down inhaled corticosteroids.

\section{Soluble CD86}

T cells express CD28 and CTLA-4 molecules, which are important for receiving activation signals from APCs, such as monocytes and dendritic cells. These molecules interact with B7 molecules on APCs, B7-1 (CD80) and B7-2, also known as CD86 (67). Soluble CD86 (sCD86) results from an alternatively spliced transcription characterised by deletion of the transmembrane domain in resting monocytes, and is found in human serum (68).

Since monocytes and dendritic cells play an important role in antigen presentation and activation of inflammatory cells, it has been speculated that SCD86 levels may be altered in asthmatics $(69,70)$. Shi et al (2004) performed a study with a population consisting in 24 adult patients with stable asthma, 28 adults with aggravated asthma, and 25 healthy adult controls in which serum CD86 expression levels where measured in stable asthmatics, acute asthmatics, and healthy controls (71). Levels of serum SCD86 were significantly higher in acute asthmatics when compared to stable asthmatics and controls. Moreover, no significant difference was found between CD86 levels in stable asthmatics and controls. This significant increase in SCD86 in acute asthmatics may be correlated with the Th1-type response featured by this more severe kind of asthma, which explains increased monocyte activity when compared to the Th2-type asthma, and consequentially the increased levels of SCD86. Should these results be confirmed and SCD86 may become a possible marker of asthma severity.

\section{Serum Amyloid A}

Just like CRP, serum amyloid A (SAA) is an APP released by the liver in response to various aggressions leading to immune responses (72). In the previously mentioned study with CRP involving 20 adult patients with asthma and 50 adult patients with rhinitis, along with 20 healthy adult controls, Buyukozturk et al (2004) also measured SAA and compared the results with the same protein levels in healthy subjects (58). The results showed significantly increased serum levels of amyloid $A$ in both patients with asthma and patients with rhinitis, compared to the healthy controls. These results suggest that SAA may be a more useful marker of asthma inflammation than CRP. However, the similar levels of SAA observed in both patients with allergic rhinitis and patients with asthma suggest that this marker does not discriminate between these two types of manifestations of the atopic syndrome $(58,73)$. However, it is crucial to stress that the levels of SAA in patients with asthma, both before and after treatment with Flixotide ${ }^{T M}$ (fluticasone propionate) and Ventolin ${ }^{T M}$ (albuterol) were 
significantly greater than in healthy controls (65), which suggests that testing for SAA levels may be sensitive enough to detect asthma inflammation even in patients on inhaled steroid treatment.

However, as far as we know, there is no study on the relevance of SAA to asthma diagnosis in elderly patients.

\section{Neopterin}

Neopterin is a pteridine derivative that is produced by activated macrophages and is a marker of immune activation (74). Mota-Pinto et al (2006) performed a study in an exclusively elderly population including 42 allergic asthmatics and 22 non-allergic asthmatics, along with 41 healthy controls, which allowed them to suggest that serum neopterin is significantly increased in non-allergic asthmatics when compared to allergic asthmatics and healthy elderly controls (75). Non-allergic asthma is generally more Th1-mediated than its allergic counterpart, and the increased neopterin levels may be related to higher macrophage activity, which could explain the results obtained. The results also suggest that serum neopterin may prove to be a useful marker for classifying asthmatic patients, including those in the elderly population (75). This may be true when classifying asthmatic patients as allergic or non-allergic, but not when attempting to discriminate between asthma and other OAD. COPD, for instance, is also characterized by Th1-type immune responses and serum neopterin levels of patients with COPD may overlap with those from non-allergic asthma. Furthermore, Frick et al (2004) showed that serum neopterin levels increase naturally with age (76), which could generate doubt about the reason for its increment in elderly patients: Are serum neopterin levels raised due to non-allergic asthma inflammation or immunosenescence? However, Mota-Pinto et al used an elderly population control group, which suggests that neopterin increase in their study was related to non-allergic asthma inflammation.

YKL-40

Chitin is commonly found in nature, as a component of the exoskeletons of crabs, the walls of fungi, or the microbial sheath of parasitic nematodes (77). Chitin cannot be synthesized by mammals, but they do synthesize chitinases, which can cleave chitin, thus playing a role in defence against chitin protected pathogens (78). YKL-40 is a chitinase like protein (also called chitinase 3 -like 1 ) that lacks chitinase activity.

Chupp et al (2007) hypothesized that the level of expression of YKL-40 would be increased in patients with asthma and would correlate with the severity of the disease (79). Therefore, these investigators performed a cross-sectional analysis of serum samples from three cohorts of adult patients with asthma, as well as from healthy adult controls. The results showed that serum YKL-40 levels were significantly higher in asthmatics compared to healthy patients. In addition, YKL-40 levels correlated positively with serum tlgE and 
peripheral blood eosinophils, thereby suggesting that YKL-40 either participates in the pathogenesis of asthma, or is a marker of its severity. Similar results were obtained by Tang et al (2009), who also reported that YKL-40 levels were significantly higher in 62 adult asthmatics compared to 64 healthy adult controls (80). Specjalski et al (2011), showed that YKL-40 levels were significantly higher in 59 adult asthmatics compared to 29 healthy adult controls, but also stressed that no relationship was found between YKL-40 levels and asthma severity, asthma control, or serum tlgE levels, somehow contradicting the results obtained in other studies (81). Nevertheless, the authors showed that serum YKL-40 levels correlated with blood eosinophilia, thus corroborating the results from Chupp et al $(79,81)$.

Serum YKL-40 appeared to be a good marker for asthma, but it was not clear whether it was a biomarker of severity or a participant in the pathogenesis of asthma. However, Bara et al (2012) showed that increased serum YKL-40 levels were positively correlated with bronchial smooth muscle cell migration, in 40 adult asthmatics, suggesting that it may be an active player in bronchial smooth muscle remodelling in asthma (82). These results potentially link YKL-40 to the pathogenesis of asthma. Nevertheless, YKL-40 levels also appear to be increased in patients with COPD (83), probably because it involves airways remodelling as well. Other diseases such as peripheral arterial disease and diabetes or pre-diabetes also showed increased expression of YKL-40 $(84,85)$. It should also be stressed that none of the existing studies were focused in elderly patients with asthma, thus making it unclear whether serum YKL-40 levels are affected by aging and immunosenescence.

\section{Leukolysin}

Leukolysin is a membrane-type metalloproteinase (MMP) that appears to be expressed only in granulocytic cells of the myeloid series, mainly in neutrophils, and is released by degranulation or shedding after stimulation with pro-inflammatory cytokines, such as IL-1 and IL-8 $(86,87)$. Because of this limited distribution in granulocytic cells, Blumenthal et al (2010) performed a study to evaluate the role of leukolysin in chronic inflammatory conditions, including atopic asthma and COPD (88). The results showed that serum leukolysin levels correlated well with serum tlgE in patients with both atopic asthma and COPD. The population consisted in 337 patients from nuclear families with asthma (including children and adults), and 122 "married-in" individuals.

No study on the behaviour of leukolysin in elderly asthma was performed, which means there is no information about how aging affects this MMP expression in inflammatory granulocytes.

\subsection{Cytokines}

As inflammatory mediators, cytokines play important roles in the pathology of asthma. Therefore, there have been multiple studies measuring cytokine concentrations in asthmatics to evaluate whether these mediators may or may not be used as markers of asthma. IFN- $\gamma$, IL1B, IL-2, IL-4, IL-5, IL-6, IL-8, IL-10, IL-17, and IL-12p70, are among the most studied serum 
cytokines in asthma. If a different serum cytokine pattern could be established for each phenotype of asthma, it would mean increased diagnostic accuracy. Thus, measuring cytokine concentrations in serum and comparing its values between the different phenotypes may turn out to be a good diagnostic tool. In the next section we further review studies of some of the cytokines that may be related to asthma.

\section{IL-8}

One of the most studied cytokines in asthma is IL-8 since it is a major chemoattractant for neutrophils $(89,90)$. IL-8 is generally correlated with the extent of neutrophilic inflammation and with disease severity. This was shown in a study by Wood et al (2012), who measured serum IL-8 levels of 26 adult patients with neutrophilic asthma, 106 adult patients with non-neutrophilic asthma, and 83 healthy adult controls (7). Serum IL-8 was significantly increased in the neutrophilic asthma group when compared to the other two groups, whereas no significant difference was found between non-neutrophilic asthma and healthy controls. These results suggest that IL-8 expression in serum correlates with the levels of neutrophilic inflammation in asthma. Furthermore, they showed that neutrophilic asthma is generally more severe with increased systemic inflammation. This supports the results from a prior study performed by Silvestri et al (2006) that involved 14 adult patients with severe asthma, 22 adult patients with mild/moderate asthma, and 20 healthy adult controls (8). The results suggest that IL-8 is significantly increased in asthmatic patients when compared to the healthy group. However, serum IL-8 levels in severe asthmatics were significantly higher than in mild/moderate asthmatics. In short, the results from these two studies suggest that severe asthma is associated with IL-8 and indirectly with neutrophilia. Silvestri et al further stated that the patients with severe asthma in their study were significantly older (mean age 56.64 (8)), which also supports the notion that elderly asthma is generally more neutrophilic and more severe. Still, Hollander et al (2007) showed that serum IL-8 levels in asthma overlap with COPD (91). 13 adult asthmatics and 25 adult patients with COPD participated in this study. As we discussed before, comorbidity is a common feature in the geriatric population and asthma is often misdiagnosed as COPD, which could be a problem when using IL-8 as a marker for elderly asthma.

\section{IL-6, IL-17 and TNF- $a$}

IL-6, IL-17 and TNF-a are three pro-inflammatory cytokines that stimulate the production of APP by the liver, and are indirectly related to systemic inflammation during asthma exacerbations $(57,92,93)$. IL-6 is also known to be elevated in COPD patients and is associated with lung function decline and systemic inflammation (94). In the previously discussed study, Wood et al (2012) analyzed serum levels of IL-6 and TNF-a in patients with neutrophilic asthma, patients with non-neutrophilic asthma, and healthy subjects (7). Although no significant difference was found in TNF-a measurement among the three groups, IL-6 serum levels were significantly increased in asthmatics, compared to healthy controls. 
Between the two asthmatic groups, IL-6 levels were significantly elevated in neutrophilic asthmatics, again suggesting that neutrophilic asthma is generally more severe. Furthermore, they compared these results with those of hs-CRP and concluded that IL- 6 is more clinically relevant as a marker of systemic inflammation than hs-CRP. Regarding TNF-a, Silvestri et al (2006) and Agache et al (2010) showed contradictory results as serum levels of TNF-a were significantly higher in severe adult asthmatics than in mild/moderate adult asthmatics and healthy adult controls $(8,15)$. Thus, TNF-a may be a possible marker for systemic inflammation in asthma. Unfortunately, there are no studies that can help us to elucidate whether TNF-a levels are affected or not by neutrophilia in severe asthmatics.

In the aforementioned study, Agache et al (2010) showed that serum IL-17 is significantly increased in 36 adult patients with severe asthma, when compared with 49 adult patients with mild and moderate asthma (15). These results suggest that IL-17 may turn out to be a good serum marker for measuring asthma severity. Moreover, they concluded that TNF-a was less discriminative in predicting asthma severity, when compared to IL-17. However, serum levels of IL-17 were shown to be inversely related to smoking habits. In other studies, IL-17 in COPD was found to be considerably elevated when compared to asthma, although no association with neutrophilic inflammation was found (95).

There are no studies evaluating these cytokines levels in elderly asthma (although Silvestri et al stated that patients in the severe asthmatics group were considerably older), nor studies comparing the same cytokines in asthma and COPD.

IL-12p70

IL12p70 is involved in dendritic and T helper cells differentiation and it is often associated with Th1 type immune responses. Thus, IL-12p70 may play a role in non-allergic asthma. In an study including 20 Dermatophagoides pteronyssinus sensitive allergic asthmatics and 20 age-matched non-atopic controls, Huang et al (2011) showed that monocyte-derived dendritic cells obtained from the allergen sensitized asthmatics produced less IL-12 when compared with the cells from the non-sensitized controls, suggesting that IL12 and consequently IL-12p70 may indeed be increased in non-atopic subjects and possibly in non-allergic asthmatics (96). Contradicting these results, Vizmanos-Lamotte et al (2013) showed that IL-12p70 was significantly increased in the allergic asthmatics when compared to the non-allergic asthmatics in their study (97). However, the population of the study consisted in 60 allergic asthmatic patients, 17 non-allergic asthmatic patients and 31 healthy controls, all of them children between 7 and 15 years old, and as the authors suggest, asthma phenotypes in children may not be stable. Furthermore, IL-12p70 was measured in the sputum.

In conclusion, IL-12p70 appears to be an interesting marker to study further, as its accuracy as a marker for allergic or non-allergic asthma is yet to be determined. 
IL-10 is known for its regulatory and suppressive properties, inhibiting autoreactivity and regulating Th1 and Th2 immune responses. Whether IL-10 plays a distinct role in patients with asthma, who may be defective in the function of Treg cells, remains unclear. Tsai et al (2009) found no significant differences in IL-10 levels between 22 allergic asthmatic children and 16 controls of matching age (98). However, Yalcin et al (2012) showed that there are in fact differences in IL-10 circulating levels related to asthma, being significantly lower in asthmatics before anti-lgE treatment, when compared to the post-treated patients (99). This suggests that IL-10 levels are indeed altered in the pathology of asthma and may be an important key to its treatment, thus more studies regarding IL-10 are necessary.

\subsection{The need for new markers}

As we could tell from all the information collected, as convenient as serum markers may seem to be, a marker capable of accurately identifying asthma with sufficient specificity is yet to be found. Furthermore, all the aforementioned markers have scarcely been studied in elderly patients. For instance, studies on the accuracy of sCD86 in elderly asthma are lacking and it is also necessary to clarify whether the significant increase observed in this marker in severe asthmatics is related to the disease itself. Further studies focusing on the geriatric population and COPD are also needed to accurately classify UTI, neopterin and leukolysin as markers for evaluating neutrophil-mediated inflammation in asthma.

When evaluating IgE as a marker of asthma, slgE appears to be more clinically relevant than tlgE for differentiating between atopic or non-atopic asthmatics. However, both specific and total IgE quantification may lose accuracy due to abnormal IgE levels produced in response to other infections. Furthermore, in elderly patients, this marker can be even less accurate since its levels are usually reduced due to natural immunosenescence (42). The same may happen in patients under pharmacotherapy, which may induce changes in serum IgE levels, thereby compromising the accuracy of the tests (100). Moreover, because elevated serum IgE levels are not an accurate discriminator of atopic asthma (especially in the geriatric population), leukolysin may indirectly share its inaccuracy as well, since changes in leukolysin levels are closely paralleled by those of tlgE in asthmatics. However, if good results are obtained in subsequent studies, leukolysin may prove to be a metabolic marker associated with atopic asthma and atopically sensitized COPD patients, that can be measured in human serum (88).

Hs-CRP and SAA appear to be more clinically reliable as markers of airway inflammation than ordinary CRP measurement, as they are able to indirectly detect asthma exacerbations. Nevertheless, they may also be increased in COPD, pneumonia and other forms of airway inflammation causing diseases. This overlap may compromise their accuracy as specific noncytokine markers of asthma but might become important as routinely used supplemental 
indicators of the severity of the disease. However, no studies have analyzed the impact of age on SAA and hs-CRP in elderly patients with asthma.

Currently, IL-8 seems to be a promising cytokine for measuring asthma severity, even in elderly asthma, although it cannot accurately distinguish between asthma and COPD. Still, it appears to be the more clinically reliable cytokine to be used as a severity marker of asthma.

ECP seems to be an interesting protein to be measured when researching for biomarkers of asthma. However, its accuracy is somehow questionable as each study presents slightly different results and its diagnostic value can vary with age, gender and the treatment patients are on.

YKL-40 positively correlates with blood eosinophilia and bronchial smooth muscle remodelling, thus appearing to be an emerging marker for asthma, that is not only related to asthma exacerbations, but also to the airways remodelling characteristic of the disease.

Altogether, clinically assessable markers capable of supporting a diagnosis of asthma are needed in order to counter misdiagnosis with other $O A D$, bearing in mind both the convenience and quality of information they provide (101). Differentiating allergic from nonallergic asthma is crucial as each phenotype can be associated with a distinct treatment. Therefore, it is essential that these novel markers are capable of diagnosing specific asthma phenotypes. This necessity becomes even more important in the case of elderly asthmatic patients, in whom morbidity is higher and symptoms often overlap with those of COPD (33). The actual process of aging may, on its own, make a diagnosis of asthma more complicated due to immunosenescence and natural changes in airways morphology, which may compromise the expression of some asthma markers. An accurate diagnosis will lead to a proper pharmacotherapy follow-up, resulting in better conditions and reduced fatality in the elderly asthmatic population.

To develop an accurate marker of asthma, one must make sure that these conditions are taken into account and controlled for, as much as possible.

\subsection{Objectives of the study}

Of all the serum biomarkers reviewed, we considered cytokines to be the ones that appeared the most promising, and therefore the ones with better accuracy for differentiating allergic from non-allergic asthma. Furthermore, there were no studies concerning cytokine measurement in the serum of elderly asthmatics.

The focal aim of our study was to measure six serum cytokines, including IL-1B, IL-6, IL8, IL-10, IL-12p70 and TNF-a, in an elderly population with asthma. We also intended to: 
1. Use flow cytometry to simultaneously quantify the cytokines, allowing us to easily compare the resulting values and establish patterns;

2. Evaluate cytokine pattern changes related to age, using a young adult control group;

3. Investigate possible cytokine pattern differences for each phenotype of asthma (allergic and non-allergic asthma). 


\section{Chapter 2}

\section{Materials and Methods}

\subsection{Study Design}

This study was carried out at the Faculty of Health Sciences of the University of Beira Interior, Covilhã.

The population of this cross-sectional study included 4 groups of individuals living in Cova da Beira, registered in the lists of general practitioners at the primary health care centre: one of healthy young adults (aged between 18 and 35), and three of elderly patients (aged 65 or older).

The individuals were chosen from a database of patients generated in a previously performed study at the same institution. The patients filled in a standardised questionnaire to identify symptoms of asthma and rhinitis, were submitted to skin-prick testing, and serum samples were collected and stored at $-20^{\circ} \mathrm{C}$ for further processing.

\subsection{Population Selection}

The patients were included in four different groups according to age, questionnaire answers, SPT and total and specific IgE (Phadiatop ${ }^{\circledR}$ ) results. Questions used as criteria for asthma were the ones concerning wheezing or treatment with asthma medication in the previous 12 months, as well as wheezing, dry cough or shortness of breath during or after exercise, according to the guidelines from the Global Initiative for Asthma report (1). In a similar manner, patients were checked for symptoms of rhinitis. Questions used as criteria for rhinitis were the ones concerning sneezing, "runny nose" (nasal dripping) or "stuffy nose" (nasal congestion) in the previous 12 months, in the absence of a cold or flu, as well as nasal symptoms accompanied by eye irritation manifested as itchy or watery eyes (rhinoconjunctivitis). If the patient had at least one positive answer to the previous questions, he/she was regarded as having clinical symptoms compatible with rhinitis, in accordance with the guidelines used by the European Academy of Allergology and Clinical Immunology (EAACI) for the ISAAC Study, adapted to an adult population (102).

SPT and total and specific IgE results determined whether the patient was atopic or non-atopic. Skin prick testing with a battery of common allergens adapted to local exposure was performed following EAACl allergen standardization and skin test recommendation (103). Before skin prick testing, relevant medication was discontinued. The tested aeroallergens included house dust mite (Dermatophagoides pteronyssinus), olive tree (Olea europaea), 
grass pollen mix, weed pollen mix and Parietaria judaica. A negative control containing the diluent used to reconstitute the allergens and a positive control consisting of histamine at $10 \mathrm{mg} / \mathrm{ml}$ were also applied. Allergen extracts were manufactured by LETI (Barcelona, Spain) and all belonged to the same batch. A skin test panel was considered valid if the correct outcomes of the controls were verified, including a histamine weal greater than $3 \mathrm{~mm}$ in diameter, along with an absence of weal at the negative control site. If the test was valid, a weal diameter of at least $3 \mathrm{~mm}$ as a reaction to any of the test allergens was regarded as a positive response. Specific and total IgE were quantified by sandwich enzyme linked immunosorbent assay (ELISA) using the Phadiatop and tlgE tests respectively, in an ImmunoCAP 250 (Phadia, Uppsala, Sweden). Any sample with slgE quantified over $0.35 \mathrm{kU} / \mathrm{l}$ was regarded as a positive Phadiatop. If the patient had a positive SPT and/or Phadiatop, he/she was regarded as atopic. In contrast, if the patient showed negative results to both SPT and Phadiatop, he/she was regarded as non-atopic. The designation "non-allergic" was applied when the SPT and serum slgE measurements were all negative. Moreover, we only included individuals with tlgE under $150 \mathrm{kU} / \mathrm{l}$ in the non-atopic elderly groups.

Using these criteria we formed four groups of individuals. The elderly allergic asthmatic group consisted in asthmatic patients aged 65 years old or over, that were regarded as atopic. Alternatively, non-atopic asthmatic patients under the same age range were included in the elderly non-allergic asthmatic group. The elderly control group consisted in non-asthmatic subjects aged 65 or over, that were also considered non-atopic. Non-asthmatic individuals aged between 18 and 35 that were also non-atopic were included in the young adult control group.

\subsection{Quantification of Cytokines}

IL-12p70, TNF-a, IL-10, IL-6, IL-1B and IL-8 serum cytokine levels were measured by flow cytometry, using the Cytometric Bead Array (CBA) Human Inflammatory Cytokines Kit (BD Biosciences, catalogue $n^{\circ} 551811$ ). The serum samples were processed according to the manufacturer instructions. The standard curve and all patient samples were acquired in the

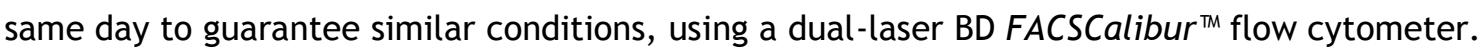
We conducted the cytometer setup according to the manufacturer manual, using cytometer setup beads and PE and FITC positive control detectors. Acquisition was performed using the BD Cell Quest ${ }^{\text {TM }}$ Pro 5.1.1 software. Cytometric Analysis was made using the BD Cytometric Bead Array v1.4 software (BD Biosciences).

\subsection{Statistical Analysis}

All statistical analysis were performed using IBM SPSS Statistics 20.0 (Statistical Package for the Social Sciences Inc., Chicago, Illinois, USA).

The data was cheeked for normal distribution using the Kolmogorov-Smirnov test. All data was analysed using non-parametric tests. Results are expressed as median and range. 
Mann-Whitney $U$ test (continuous variables) and chi-square test (categorical variables) were used for comparisons between two groups. Kruskal-Wallis test was used for non-parametric comparison of quantitative data between the four groups.

A $p$ value of less than 0.05 was considered statistically significant. 


\section{Chapter 3}

\section{Results}

\subsection{Study Population}

In this study, 45 elderly patients were included in three different groups with 16 being included in the allergic asthmatic group, 20 into the non-allergic asthmatic group, and finally 9 into the elderly control group. Eleven (11) young adult controls were also recruited, making a total of 56 individuals (Figure 1).

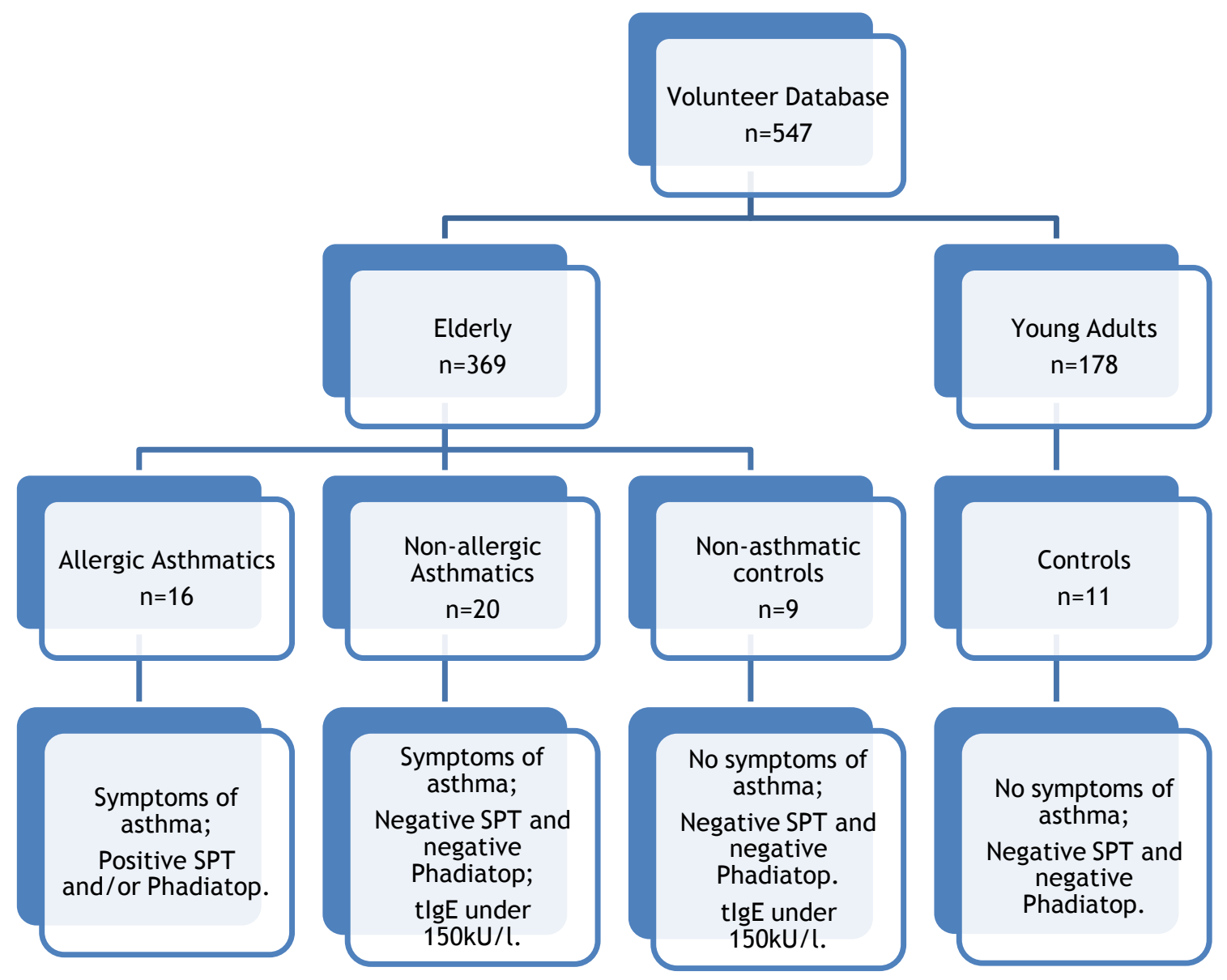

Figure 1 - Flow-chart of the methodology used for group selection.

The three elderly groups were paired according to age ( $p=0.574$; Chi-square test), but not to sex. Twenty-three (23) individuals out of 56 were male. Furthermore, 4 out of 16 patients had allergic asthma along with allergic rhinitis, in the allergic asthmatic group. 
Moreover, in this group, all patients had positive Phadiatop values $(>0.35 \mathrm{kU})$, although 6 out of 16 showed negative SPT. In addition, tlgE was significantly increased in elderly allergic asthmatics in comparison with the other three groups $(p<0.001)$. Furthermore, there was no significant difference in tlgE levels between non-allergic asthmatics and both control groups (Table 1).

Table 1 - Characterization of the study population.

\begin{tabular}{c|cccc}
\hline \multirow{2}{*}{ Characteristics } & \multicolumn{2}{c}{ Control Subjects $(\mathrm{n}=20)$} & \multicolumn{2}{c}{ Elderly Asthmatics $(\mathrm{n}=36)$} \\
\cline { 2 - 5 } & Elderly $(\mathrm{n}=9)$ & $\begin{array}{c}\text { Young Adults } \\
(\mathrm{n}=11)\end{array}$ & Allergic $(\mathrm{n}=16)$ & $\begin{array}{c}\text { Non-Allergic } \\
(\mathrm{n}=20)\end{array}$ \\
\hline Age (years) & $73,7[65 ; 86]$ & $27,5[19 ; 34]$ & $74,0[65 ; 85]$ & $71,8[65 ; 85]$ \\
Gender (male/total) & $3 / 9$ & $8 / 11$ & $8 / 16$ & $4 / 20$ \\
Rhinitis (yes/total) & $0 / 9$ & $0 / 11$ & $4 / 16$ & $0 / 20$ \\
SPT (positive/total) & $0 / 9$ & $0 / 11$ & $10 / 16$ & $0 / 20$ \\
$\begin{array}{c}\text { Phadiatop } \\
\text { (positive/total) }\end{array}$ & $0 / 9$ & $0 / 11$ & $16 / 16$ & $0 / 20$ \\
Total IgE & $7,1 \mathrm{kU} / \mathrm{l}[2.4 ;$ & $29,9 \mathrm{kU} / \mathrm{l}[5.6 ;$ & $160,0 \mathrm{kU} / \mathrm{l}[19.5 ;$ & $16,8[<2 ; 112.0]$ \\
\hline
\end{tabular}

\subsection{Flow Cytometry}

We followed the instruction manual on the kit to define the cytometer instruments settings for acquisition. The beads cluster could clearly be seen in a forward scatter - side scatter dot plot. We drew a region containing the beads, as we can see in Figure 2 . In this figure example, the beads are visible inside the regions drawn in $\mathrm{A}$ and $\mathrm{C}$, which represent forward scatter - side scatter dot plots for a $0 \mathrm{pg} / \mathrm{ml}$ standard and a sample of serum from a patient, respectively. $B$ and $D$ represent a gated view of the region containing the beads, in FL-2 - FL-3 dot plots, which allowed us to quantify the emitted fluorescence, thus indirectly measuring the median levels of the cytokine in the serum. It is possible to see in $B$ and $D$ how the dots formed separated clusters for each cytokine. Using the BD Cytometric Bead Array software we drew a standard curve using bead standards (see attachments section, page 41), which allowed us to relate the fluorescence detected in FL2 to the approximate amount of each cytokine in serum. 
A

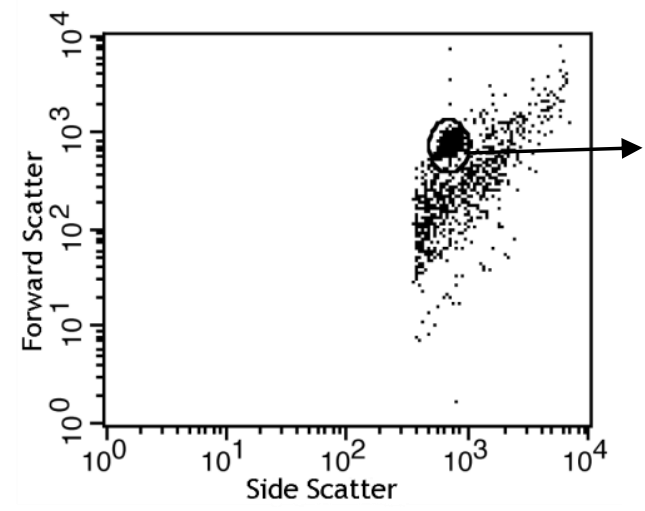

C

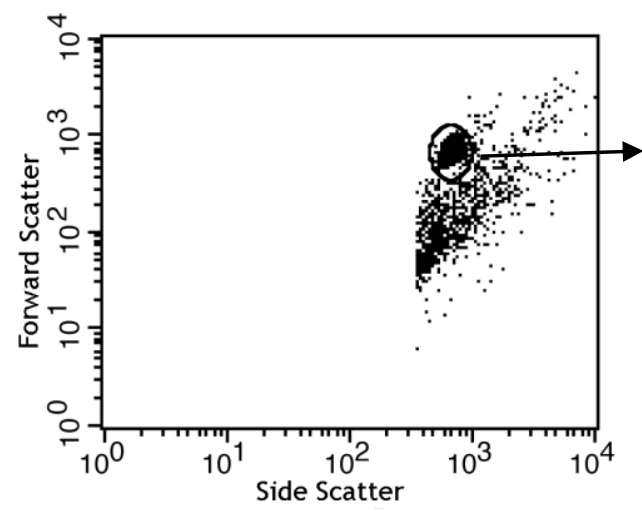

B

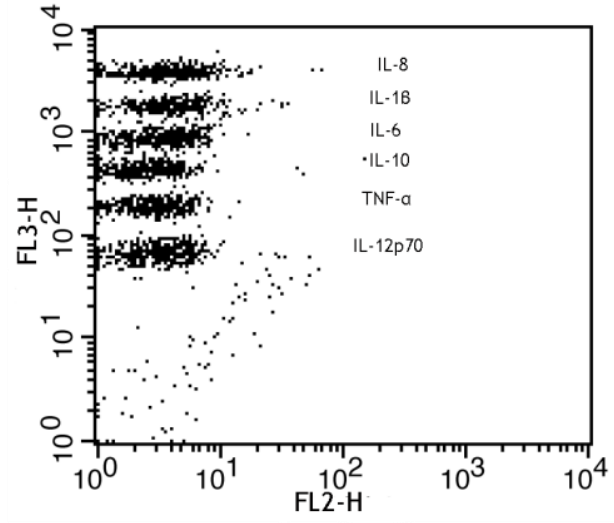

D

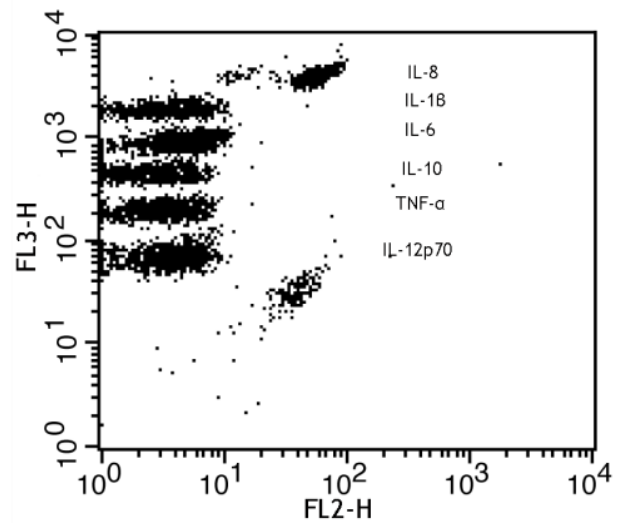

Figure 2 - Example of two acquisition cases. A - Analysis of a $0 \mathrm{pg} / \mathrm{ml}$ standard in a forward scatter side scatter dot plot. B - A gated FL-2 - FL3 dot plot intercalated with the region drawn in A. We can see the beads clustering closely to the $y$ axis, representing $0 \mathrm{pg} / \mathrm{ml}$ for each cytokine. C - Analysis of a sample of serum from a patient in a forward scatter - side scatter dot plot. D - A gated FL-2 - FL3 dot plot intercalated with the region drawn in B. We can see that IL-8 is increased in FL2, when compared to the $0 \mathrm{pg} / \mathrm{ml}$ standard.

Table 2 - Median [max; min] levels of the studied cytokines, sorted by groups.

\begin{tabular}{c|cccc}
\hline \multirow{2}{*}{ Cytokines } & \multicolumn{2}{c}{ Control Subjects $(\mathrm{n}=20)$} & \multicolumn{2}{c}{ Elderly Asthmatics $(\mathrm{n}=36)$} \\
\cline { 2 - 5 } & Elderly $(\mathrm{n}=9)$ & Young Adults $(\mathrm{n}=11)$ & Allergic $(\mathrm{n}=16)$ & Non-Allergic $(\mathrm{n}=20)$ \\
\hline IL-12p70 $(\mathrm{pg} / \mathrm{mL})$ & 0,0 & 0,0 & 0,0 & 0,0 \\
TNF-a $(\mathrm{pg} / \mathrm{mL})$ & $5,3[0,0 ; 8,5]$ & $7,6[0,0 ; 10,2]$ & $6,5[0,0 ; 12,6]$ & $7,7[0,0 ; 17,6]$ \\
IL-10 $(\mathrm{pg} / \mathrm{mL})$ & $0,2[0,0 ; 1,5]$ & $0,6[0,0 ; 1,8]$ & $0,4[0,0 ; 3,4]$ & $0,9[0,0 ; 5,2]$ \\
IL-6 $(\mathrm{pg} / \mathrm{mL})$ & $4,5[0,0 ; 75,5]$ & $4,9[0,0 ; 7,2]$ & $4,8[0,0 ; 17,7]$ & $6,0[0,0 ; 74,8]$ \\
IL-1B $(\mathrm{pg} / \mathrm{mL})$ & $9,7[0,0 ; 11,6]$ & $11,5[0,0 ; 18,1]$ & $10,0[0,0 ; 25,7]$ & $11,2[0,0 ; 24,4]$ \\
IL-8 $(\mathrm{pg} / \mathrm{mL})$ & $11,7[0,0 ; 43,1]$ & $0,2[0,0 ; 114,7]$ & $11,4[0,0 ; 132,9]$ & $27,1[0,0 ; 153,4]$ \\
\hline
\end{tabular}

Table 2 presents a summary of the median levels of the cytokines quantified, including minimum and maximum values. IL-12p70 was not detected in any subject. TNF-a, IL-10 and IL-8 levels were increased in the non-allergic asthmatics group, although with no statistical 
significance $(p=0.163 ; 0.054 ; 0.092$ respectively; Mann-Whitney $U$ test). IL- 6 was significantly increased in the elderly non-allergic asthmatic group, when compared to both control groups ( $p=0.033$; Mann-Whitney $U$ test) and when compared to the young adult controls alone $(p=0.044$; Mann-Whitney $U$ test), but no significant differences were found when comparing to the elderly control group separately ( $p=0.167$; Mann-Whitney $U$ test). IL-1B median levels were shown to be elevated in the young adults control group, but also without statistical significant difference ( $p=0.322$; Mann-Whitney $U$ test). IL-8 was generally increased in the elderly, when compared to the young adults group, although without significance $(p=0.079$; Mann-Whitney U test).

No significant different was found when comparing the four groups altogether $(p>0.05$ for all cytokines; Kruskal-Wallis test).

Figures 3 to 7 show boxplots of the cytokine values measured in each group of individuals.

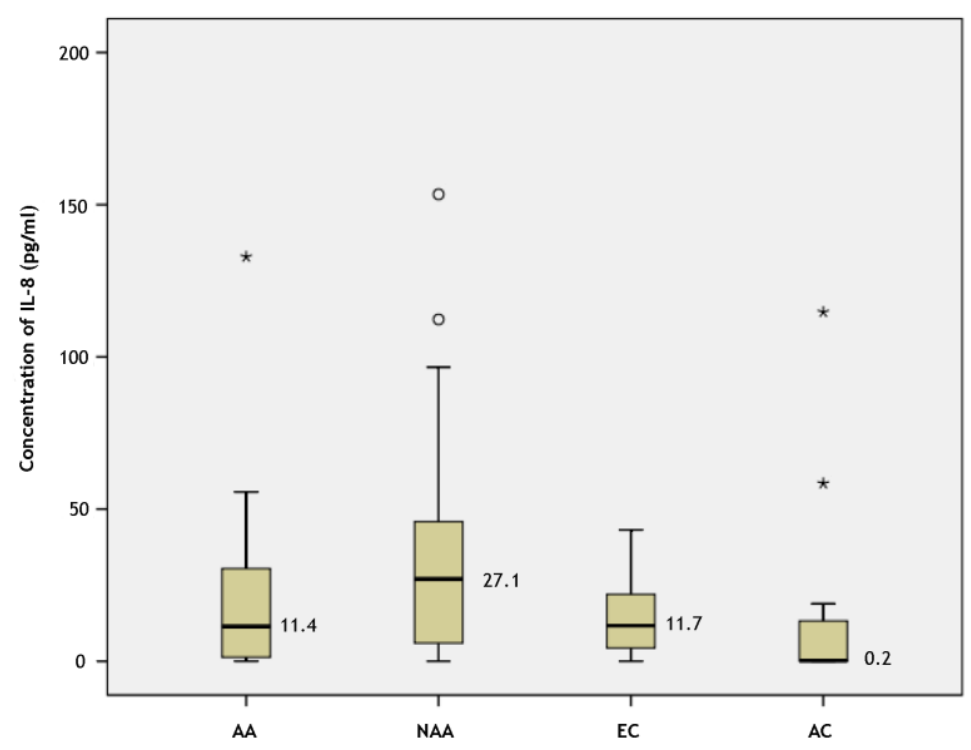

Figure 3 - Box plot of the measured concentrations of IL-8, sorted by groups. AA= Allergic Asthmatics; $\mathrm{NAA}=$ Non-allergic Asthmatics; $\mathrm{EC}=$ Elderly Controls; $\mathrm{AC}=$ Young Adult Controls. The ${ }^{\circ}$ symbols represent the outliers and the * represent the extreme outliers. The horizontal black lines and the numbers represent the median for each group. 


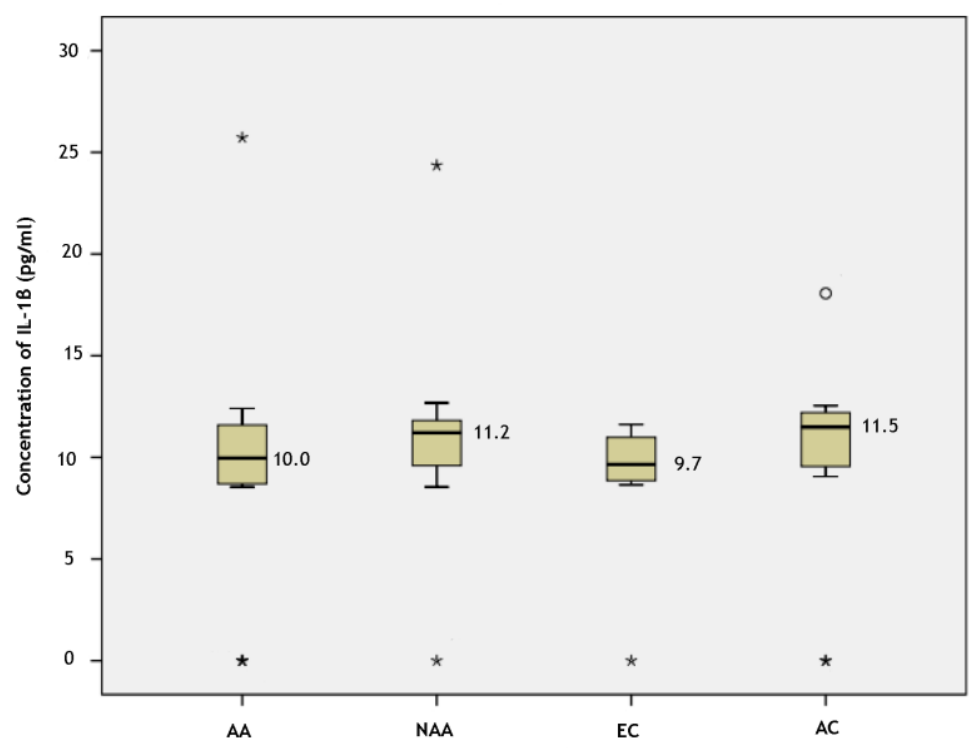

Figure 4 - Box plot of the measured concentrations of IL-1B, sorted by groups. $A A=$ Allergic Asthmatics; $\mathrm{NAA}=$ Non-allergic Asthmatics; $\mathrm{EC}=$ Elderly Controls; $\mathrm{AC}=$ Young Adult Controls. The ${ }^{\circ}$ symbols represent the outliers and the * represent the extreme outliers. The horizontal black lines and the numbers represent the median for each group.

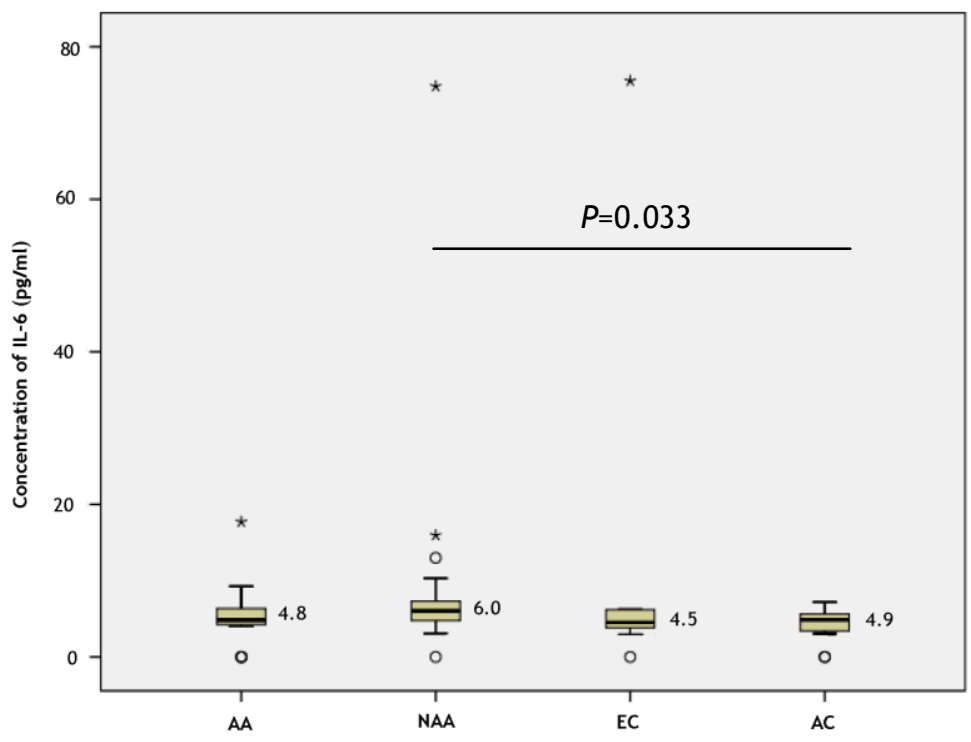

Figure 5 - Box plot of the measured concentrations of IL-6, sorted by groups. AA= Allergic Asthmatics; $\mathrm{NAA}=$ Non-allergic Asthmatics; EC= Elderly Controls; $\mathrm{AC}=$ Young Adult Controls. IL-6 is significantly increased in the non-allergic asthmatics group (NAA), when compared to the young adult control group $(\mathrm{AC})$. The ${ }^{\circ}$ symbols represent the outliers and the * represent the extreme outliers. The horizontal black lines and the numbers represent the median for each group. 


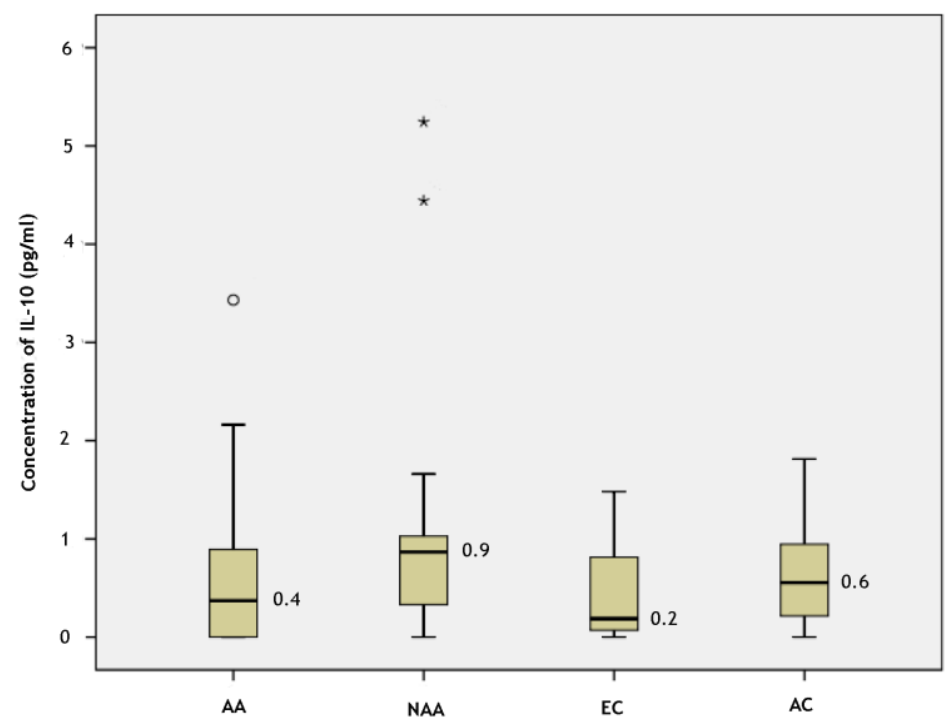

Figure 6 - Box plot of the measured concentrations of IL-10, sorted by groups. AA= Allergic Asthmatics; $\mathrm{NAA}=$ Non-allergic Asthmatics; $\mathrm{EC}=$ Elderly Controls; $\mathrm{AC}=$ Young Adult Controls. The ${ }^{\circ}$ symbols represent the outliers and the * represent the extreme outliers. The horizontal black lines and the numbers represent the median for each group.

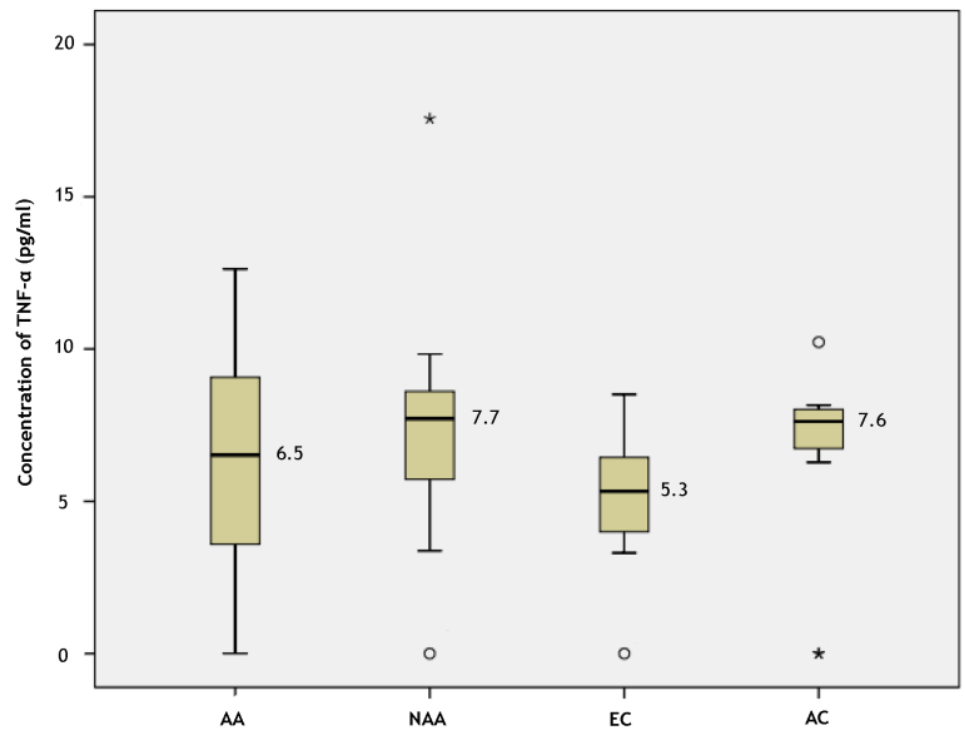

Figure 7 - Box plot of the measured concentrations of TNF-a, sorted by groups. AA= Allergic Asthmatics; $\mathrm{NAA}=$ Non-allergic Asthmatics; $\mathrm{EC}=$ Elderly Controls; $\mathrm{AC}=$ Young Adult Controls. The ${ }^{\circ}$ symbols represent the outliers and the ${ }^{*}$ represent the extreme outliers. The horizontal black lines and the numbers represent the median for each group. 


\section{Chapter 4}

\section{Discussion and Conclusions}

To the best of our knowledge, this is the first study measuring and comparing inflammatory cytokine levels in elderly patients with different asthma phenotypes using flow cytometry. A similarly designed study performed by Vizmanos-Lamotte and collaborators (2013), involving quantification of inflammatory cytokines in the sputum of children with atopic and non-atopic asthma, also by flow cytometry, suggests the importance of determining a cytokine profile for asthma diagnosis, as well as the importance of flow cytometry to achieve this purpose (97). Moreover, the reason of using this technique, rather than an enzymatic immunoassay, is because it is possible to analyse all six cytokines simultaneously, thus being easier to compare the different groups involved in the study. In addition, it requires very little volume of serum to run an analysis, when compared to other cytokine quantification assays, such as ELISA. Furthermore, flow cytometry is a fast quantification tool that allows the user to easily store considerable amounts of information, which can be analysed at any time following acquisition. If cytokines would show sufficient accuracy as markers of asthma, then flow cytometry might become a potential technique for asthma diagnosis.

Similarly to other studies, we showed that tlgE is significantly increased in the allergic asthmatic group, and although it cannot be considered a marker for atopy, it further suggests that the patients in this group were indeed atopic (54).

Although not statistically significant, our results showed that IL-8, and TNF-a median levels were increased in the non-allergic asthmatic group, which is in accordance with the results from previous studies $(7,8,15)$.

IL-6 was significantly increased in the non-allergic asthmatic group, when compared to both control groups and to the young adult control group alone. Being IL-6 a marker of severity, our results suggest that non-allergic asthma is a more severe form of the disease, which is in accordance with many previously performed studies on non-allergic asthma (7, 36, 39). Unexpectedly, no statistically significant difference was found when comparing the nonallergic asthmatic group with the elderly control group alone. Elderly patients normally suffer from concomitant diseases, such as COPD, which may also increase IL-6 serum levels to promote neutrophilic activation. This could justify the increased levels of inflammatory cytokines in some patients in the elderly control group, thus being a possible reason for the 
lack of significant differences in IL-6 serum levels between the non-allergic asthmatics and the elderly controls.

IL-12p70 could not be detected in any subject. Previous studies reported similar results, such as the one performed by Hirose et al (104). Furthermore, Dabitao et al (2011) evaluated the CBA assay for the quantification of the same cytokines in the serum of patients with HIV and healthy controls, using a FACSCalibur ${ }^{\text {TM }}$ flow cytometer as well, and compared with the Meso Scale Discovery (MSD) assay using a dedicated electrochemiluminescence analyzer (105). They concluded that the recovery of IL-12p70 and TNF-a was more accurate using the MSD technique than the CBA, although neither method quantified IL-1B accurately. In addition, when the authors measured the cytokines in the serum of the study subjects, the CBA assay did not quantify the levels of IL-12p70 and TNF- $a$ in any of the specimens (including controls), results that they further justified to be caused by a probably high detection limit.

Regarding the level of the cytokines, the differences between our results and those of other studies may be explained by variations in the asthmatic population and by the existence of possible phenotypes of asthma other than allergic or non-allergic (33). Natural variations of cytokine concentrations in the serum may also be responsible, especially because the serum samples were frozen for a long period before quantification. Many studies report characteristic changes in frozen serum when compared to fresh samples, which may also influence the levels of cytokines due to their short half-life time when in an extracellular environment (106). Other reasons such as differences in the SPT and sample collection techniques, as well as variations of the methods and kits used for the cytokine assays, may also explain the dissimilar results.

Our study has some limitations. For instance, all volunteers were included through questionnaire answers but no complementary tests, such as spirometry or FeNO, were performed to clinically confirm the pathology. In addition, since answers to background questions depend, in part, on the memories of the individuals, further information bias may also occur. It must also be taken into account that the participation was volunteer, which may have generated unfair results as patients tend to respond if they identify themselves with the subject or problem of the study.

Concluding, the main aim of measuring serum inflammatory cytokines in an elderly population with asthma was accomplished for the first time. Unfortunately, it was not possible to define a pattern of changes in cytokines levels related to phenotype differences or aging. It is possible to notice a trend for increased levels of severity cytokines, in particular IL-6, IL-8 and TNF-a $(7,8,15)$, in non-allergic asthmatic elderly individuals, which suggests that this phenotype of asthma is indeed more severe than its counterpart. 


\subsection{Future Prospects}

The search for a promising marker to accurately diagnose elderly asthma continues, and more tests on the aforementioned biomarkers should be performed. In the future, we recommend acquiring clinical confirmation of the pathology, given by a specialist, prior to the inclusion of the volunteers in each group. They should also be submitted to complementary tests, such as spirometry and FeNO, thus evading possible subject misplacement. IL-6 and IL- 8 were the two most promising cytokines, and of all the six studied cytokines, these two are the ones we recommend for further studies. Quantification using the MSD assay should not be necessary since it appears to give similar results to CBA for IL-8 and IL-6 measurement (105).

Other markers such as YKL-40 and ECP appear to have some potential for asthma monitorisation, and should be further investigated. 


\section{Chapter 5}

\section{References}

The references were listed following the Vancouver style.

1. GINA. Global stategy for asthma management and prevention. 2011. Epub 2011.

2. Tattersfield AE, Knox AJ, Britton JR, Hall IP. Asthma. Lancet. 2002;360(9342):1313-22.

3. Anand P, Singh B, Jaggi AS, Singh N. Mast cells: an expanding pathophysiological role from allergy to other disorders. Naunyn Schmiedebergs Arch Pharmacol. 2012;385(7):65770.

4. Amin K. The role of mast cells in allergic inflammation. Respir Med. 2012;106(1):9-14.

5. Langier S, Sade K, Kivity S. Regulatory T cells in allergic asthma. Isr Med Assoc J. 2012;14(3):180-3.

6. Galli SJ, Tsai M. IgE and mast cells in allergic disease. Nat Med. 2012;18(5):693-704.

7. Wood LG, Baines KJ, Fu J, Scott HA, Gibson PG. The neutrophilic inflammatory phenotype is associated with systemic inflammation in asthma. Chest. 2012;16:16.

8. Silvestri M, Bontempelli M, Giacomelli M, Malerba M, Rossi GA, Di Stefano A, et al. High serum levels of tumour necrosis factor-alpha and interleukin-8 in severe asthma: markers of systemic inflammation? Clinical and experimental allergy : journal of the British Society for Allergy and Clinical Immunology. 2006;36(11):1373-81.

9. Baines KJ, Simpson JL, Bowden NA, Scott RJ, Gibson PG. Differential gene expression and cytokine production from neutrophils in asthma phenotypes. The European respiratory journal : official journal of the European Society for Clinical Respiratory Physiology. 2010;35(3):522-31.

10. Robinson DS. Regulatory $T$ cells and asthma. Clinical and experimental allergy : journal of the British Society for Allergy and Clinical Immunology. 2009;39(9):1314-23.

11. Milner JD. IL-17 producing cells in host defense and atopy. Curr Opin Immunol. 2011;23(6):784-8.

12. Milovanovic M, Drozdenko G, Weise C, Babina M, Worm M. Interleukin-17A promotes IgE production in human B cells. J Invest Dermatol. 2010;130(11):2621-8.

13. Chang Y, Al-Alwan L, Risse PA, Roussel L, Rousseau S, Halayko AJ, et al. TH17 cytokines induce human airway smooth muscle cell migration. The Journal of allergy and clinical immunology. 2011;127(4):1046-53.

14. Besnard AG, Sabat R, Dumoutier L, Renauld JC, Willart M, Lambrecht B, et al. Dual Role of IL-22 in allergic airway inflammation and its cross-talk with IL-17A. American journal of respiratory and critical care medicine. 2011;183(9):1153-63.

15. Agache I, Ciobanu C, Agache C, Anghel M. Increased serum IL-17 is an independent risk factor for severe asthma. Respir Med. 2010;104(8):1131-7.

16. Silverpil E, Linden A. IL-17 in human asthma. Expert Rev Respir Med. 2012;6(2):173-86.

17. Ling EM, Smith $T$, Nguyen XD, Pridgeon C, Dallman M, Arbery J, et al. Relation of CD4+CD25+ regulatory T-cell suppression of allergen-driven T-cell activation to atopic status and expression of allergic disease. Lancet. 2004;363(9409):608-15.

18. Black JL, Panettieri RA, Jr., Banerjee A, Berger P. Airway smooth muscle in asthma: just a target for bronchodilation? Clin Chest Med. 2012;33(3):543-58. 
19. Hirst SJ, Martin JG, Bonacci JV, Chan V, Fixman ED, Hamid QA, et al. Proliferative aspects of airway smooth muscle. The Journal of allergy and clinical immunology. 2004;114(2 Suppl):S2-17.

20. McParland BE, Tait RR, Pare PD, Seow CY. The role of airway smooth muscle during an attack of asthma simulated in vitro. Am J Respir Cell Mol Biol. 2005;33(5):500-4.

21. Burney PG, Newson RB, Burrows MS, Wheeler DM. The effects of allergens in outdoor air on both atopic and nonatopic subjects with airway disease. Allergy. 2008;63(5):542-6.

22. Newson R, Strachan D, Archibald E, Emberlin J, Hardaker P, Collier C. Acute asthma epidemics, weather and pollen in England, 1987-1994. The European respiratory journal : official journal of the European Society for Clinical Respiratory Physiology. 1998;11(3):694-701.

23. Bumbacea D, Campbell D, Nguyen L, Carr D, Barnes PJ, Robinson D, et al. Parameters associated with persistent airflow obstruction in chronic severe asthma. The European respiratory journal : official journal of the European Society for Clinical Respiratory Physiology. 2004;24(1):122-8.

24. Fahy JV. Eosinophilic and neutrophilic inflammation in asthma: insights from clinical studies. Proceedings of the American Thoracic Society. 2009;6(3):256-9.

25. Green RH, Brightling CE, Woltmann G, Parker D, Wardlaw AJ, Pavord ID. Analysis of induced sputum in adults with asthma: identification of subgroup with isolated sputum neutrophilia and poor response to inhaled corticosteroids. Thorax. 2002;57(10):875-9.

26. Thomson NC, Chaudhuri R. Asthma in smokers: challenges and opportunities. Current opinion in pulmonary medicine. 2009;15(1):39-45.

27. Tinkelman DG, Price DB, Nordyke RJ, Halbert RJ, Isonaka S, Nonikov D, et al. Symptombased questionnaire for differentiating COPD and asthma. Respiration. 2006;73(3):296305.

28. Mathur SK. Allergy and asthma in the elderly. Semin Respir Crit Care Med. 2010;31(5):587-95.

29. Fabbri LM, Romagnoli M, Corbetta L, Casoni G, Busljetic K, Turato G, et al. Differences in airway inflammation in patients with fixed airflow obstruction due to asthma or chronic obstructive pulmonary disease. American journal of respiratory and critical care medicine. 2003;167(3):418-24.

30. Price DB, Tinkelman DG, Halbert RJ, Nordyke RJ, Isonaka S, Nonikov D, et al. Symptombased questionnaire for identifying COPD in smokers. Respiration. 2006;73(3):285-95.

31. Yorgancioglu A, Sakar Coskun A. Is the diagnosis of asthma different in elderly? Tuberk Toraks. 2012;60(1):81-5.

32. Lindner K, Panaszek B, Machaj Z. [Asthma in the elderly]. Pol Arch Med Wewn. 2007;117(8):350-4.

33. O'Neil SE, Lundback B, Lotvall J. Proteomics in asthma and COPD phenotypes and endotypes for biomarker discovery and improved understanding of disease entities. J Proteomics. 2011;75(1):192-201.

34. Bom AT, Pinto AM. Allergic respiratory diseases in the elderly. Respir Med. 2009;103(11):1614-22.

35. Harik-Khan RI, Wise RA, Fozard JL. Determinants of maximal inspiratory pressure. The Baltimore Longitudinal Study of Aging. American journal of respiratory and critical care medicine. 1998;158(5 Pt 1):1459-64.

36. Kim HY, DeKruyff RH, Umetsu DT. The many paths to asthma: phenotype shaped by innate and adaptive immunity. Nat Immunol. 2010;11(7):577-84.

37. Robinson DS, Hamid Q, Ying S, Tsicopoulos A, Barkans J, Bentley AM, et al. Predominant TH2-like bronchoalveolar T-lymphocyte population in atopic asthma. N Engl J Med. 1992;326(5):298-304. 
38. Holgate ST, Polosa R. Treatment strategies for allergy and asthma. Nat Rev Immunol. 2008;8(3):218-30.

39. Knudsen TB, Thomsen SF, Nolte H, Backer V. A population-based clinical study of allergic and non-allergic asthma. The Journal of asthma : official journal of the Association for the Care of Asthma. 2009;46(1):91-4.

40. Janeway CA, Jr., Medzhitov R. Innate immune recognition. Annu Rev Immunol. 2002;20:197-216.

41. Simpson JL, Grissell TV, Douwes J, Scott RJ, Boyle MJ, Gibson PG. Innate immune activation in neutrophilic asthma and bronchiectasis. Thorax. 2007;62(3):211-8.

42. Scichilone N, Callari A, Augugliaro G, Marchese M, Togias A, Bellia V. The impact of age on prevalence of positive skin prick tests and specific IgE tests. Respir Med. 2011;105(5):651-8.

43. Todo-Bom A, Mota-Pinto A, Alves V, Santos-Rosa M. Aging and asthma - changes in CD45RA, CD29 and CD95 T cells subsets. Allergol Immunopathol. 2012;40(1):14-9.

44. Todo-Bom A, Mota Pinto A, Alves V, Vale Pereira S, Santos Rosa M. Apoptosis and asthma in the elderly. J Investig Allergol Clin Immunol. 2007;17(2):107-12.

45. Jayaraman S, Castro M, O'Sullivan M, Bragdon MJ, Holtzman MJ. Resistance to Fasmediated T cell apoptosis in asthma. J Immunol. 1999;162(3):1717-22.

46. Fortuna AM, Feixas T, Gonzalez M, Casan P. Diagnostic utility of inflammatory biomarkers in asthma: exhaled nitric oxide and induced sputum eosinophil count. Respir Med. 2007;101(11):2416-21.

47. Munakata M. Exhaled Nitric Oxide (FeNO) as a Non-Invasive Marker of Airway Inflammation. Allergology international : official journal of the Japanese Society of Allergology. 2012;61(3):365-72.

48. Patelis A, Gunnbjornsdottir M, Malinovschi A, Matsson P, Onell A, Hogman M, et al. Population-based study of multiplexed IgE sensitization in relation to asthma, exhaled nitric oxide, and bronchial responsiveness. The Journal of allergy and clinical immunology. 2012;130(2):397-402.

49. Tilemann L, Gindner L, Meyer F, Szecsenyi J, Schneider A. Differences in local and systemic inflammatory markers in patients with obstructive airways disease. Prim Care Respir J. 2011;20(4):407-14.

50. Fajraoui N, Charfi MR, Khouani H, Abouda M, Kerkenil Y, Zouari B. [Contribution of serum total immunoglobulin $\mathrm{E}$ measurement in the diagnosis of respiratory allergic diseases]. Tunis Med. 2008;86(1):32-7.

51. Urban JF, Jr., Katona IM, Dean DA, Finkleman FD. The cellular IgE response of rodents to infection with Nippostrongylus brasiliensis, Trichinella spiralis and Schistosoma mansoni. Vet Parasitol. 1984;14(3-4):193-208.

52. van den Biggelaar AH, Rodrigues LC, van Ree R, van der Zee JS, Hoeksma-Kruize YC, Souverijn $\mathrm{JH}$, et al. Long-term treatment of intestinal helminths increases mite skin-test reactivity in Gabonese schoolchildren. J Infect Dis. 2004;189(5):892-900.

53. Mandelin JM, Remitz A, Virtanen HM, Malmberg LP, Haahtela T, Reitamo S. A 10-year open follow-up of eczema and respiratory symptoms in patients with atopic dermatitis treated with topical tacrolimus for the first 4 years. J Dermatolog Treat. 2010;21(3):16770.

54. Szefler SJ, Wenzel S, Brown R, Erzurum SC, Fahy JV, Hamilton RG, et al. Asthma outcomes: biomarkers. The Journal of allergy and clinical immunology. 2012;129(3 Suppl):S9-23. Epub 2012/03/14.

55. Wood RA, Phipatanakul W, Hamilton RG, Eggleston PA. A comparison of skin prick tests, intradermal skin tests, and RASTs in the diagnosis of cat allergy. The Journal of allergy and clinical immunology. 1999;103(5 Pt 1):773-9. 
56. King MJ, Bukantz SC, Phillips S, Mohapatra SS, Tamulis T, Lockey RF. Serum total IgE and specific IgE to Dermatophagoides pteronyssinus, but not eosinophil cationic protein, are more likely to be elevated in elderly asthmatic patients. Allergy and asthma proceedings : the official journal of regional and state allergy societies. 2004;25(5):321-5.

57. Gabay C, Kushner I. Acute-phase proteins and other systemic responses to inflammation. N Engl J Med. 1999;340(6):448-54.

58. Buyukozturk S, Gelincik AA, Genc S, Kocak H, Oneriyidogan Y, Erden S, et al. Acute phase reactants in allergic airway disease. Tohoku J Exp Med. 2004;204(3):209-13.

59. Bafadhel M, Clark TW, Reid C, Medina MJ, Batham S, Barer MR, et al. Procalcitonin and C-reactive protein in hospitalized adult patients with community-acquired pneumonia or exacerbation of asthma or COPD. Chest. 2011;139(6):1410-8.

60. Allam MH, Said AF, El Samie Omran AA, Abd El-Reheim DM, Kasem AH. High sensitivity Creactive protein: its correlation with sputum cell counts in bronchial asthma. Respir Med. 2009;103(12):1878-84.

61. Yasui K, Kanda H, Iwanami T, Komiyama A. Increased serum concentration of urinary trypsin inhibitor with asthma exacerbation. The European respiratory journal : official journal of the European Society for Clinical Respiratory Physiology. 2003;22(5):739-42.

62. Denburg JA, Keith PK. Eosinophil progenitors in airway diseases: clinical implications. Chest. 2008;134(5):1037-43.

63. Venge P. Monitoring the allergic inflammation. Allergy. 2004;59(1):26-32.

64. Peona V, De Amici M, Quaglini S, Bellaviti G, Castellazzi AM, Marseglia G, et al. Serum eosinophilic cationic protein: is there a role in respiratory disorders? The Journal of asthma : official journal of the Association for the Care of Asthma. 2010;47(2):131-4.

65. Ozseker F, Buyukozturk S, Depboylu B, Yilmazbayhan D, Karayigit E, Gelincik A, et al. Serum amyloid $A(S A A)$ in induced sputum of asthmatics: a new look to an old marker. Int Immunopharmacol. 2006;6(10):1569-76.

66. Koh GC, Shek LP, Goh DY, Van Bever H, Koh DS. Eosinophil cationic protein: is it useful in asthma? A systematic review. Respir Med. 2007;101(4):696-705.

67. Greenfield EA, Nguyen KA, Kuchroo VK. CD28/B7 costimulation: a review. Crit Rev Immunol. 1998;18(5):389-418.

68. Jeannin P, Magistrelli G, Aubry JP, Caron G, Gauchat JF, Renno T, et al. Soluble CD86 is a costimulatory molecule for human T lymphocytes. Immunity. 2000;13(3):303-12.

69. Tsuyuki S, Tsuyuki J, Einsle K, Kopf M, Coyle AJ. Costimulation through B7-2 (CD86) is required for the induction of a lung mucosal T helper cell $2(\mathrm{TH} 2)$ immune response and altered airway responsiveness. J Exp Med. 1997;185(9):1671-9.

70. Burr JS, Kimzey SL, Randolph DR, Green JM. CD28 and CTLA4 coordinately regulate airway inflammatory cell recruitment and T-helper cell differentiation after inhaled allergen. Am J Respir Cell Mol Biol. 2001;24(5):563-8.

71. Shi HZ, Xie ZF, Deng JM, Chen YQ, Xiao CQ. Soluble CD86 protein in serum samples of patients with asthma. Thorax. 2004;59(10):870-5.

72. Urieli-Shoval S, Cohen P, Eisenberg S, Matzner Y. Widespread expression of serum amyloid $\mathrm{A}$ in histologically normal human tissues. Predominant localization to the epithelium. J Histochem Cytochem. 1998;46(12):1377-84.

73. Braunstahl GJ, Fokkens WJ, Overbeek SE, KleinJan A, Hoogsteden HC, Prins JB. Mucosal and systemic inflammatory changes in allergic rhinitis and asthma: a comparison between upper and lower airways. Clinical and experimental allergy : journal of the British Society for Allergy and Clinical Immunology. 2003;33(5):579-87.

74. Kaski JC, Avanzas P, Arroyo-Espliguero R. Neopterin--a forgotten biomarker: J Am Coll Cardiol. 2003 Sep 17;42(6):1142-3. 
75. Mota Pinto A, Todo Bom A, Vale Pereira S, Alves V, Santos Rosa M. Elevated neopterin levels in non-allergic asthma. Pathophysiology. 2006;14(1):35-9.

76. Frick B, Schroecksnadel K, Neurauter G, Leblhuber F, Fuchs D. Increasing production of homocysteine and neopterin and degradation of tryptophan with older age. Clin Biochem. 2004;37(8):684-7.

77. Elias JA, Homer RJ, Hamid Q, Lee CG. Chitinases and chitinase-like proteins in $T(H) 2$ inflammation and asthma. The Journal of allergy and clinical immunology. 2005;116(3):497-500.

78. Kawada M, Hachiya $Y$, Arihiro A, Mizoguchi E. Role of mammalian chitinases in inflammatory conditions. Keio J Med. 2007;56(1):21-7.

79. Chupp GL, Lee CG, Jarjour N, Shim YM, Holm CT, He S, et al. A chitinase-like protein in the lung and circulation of patients with severe asthma. $N$ Engl J Med. 2007;357(20):2016-27.

80. Tang H, Fang Z, Sun Y, Li B, Shi Z, Chen J, et al. YKL-40 in asthmatic patients, and its correlations with exacerbation, eosinophils and immunoglobulin E. The European respiratory journal : official journal of the European Society for Clinical Respiratory Physiology. 2010;35(4):757-60.

81. Specjalski K, Jassem E. YKL-40 protein is a marker of asthma. The Journal of asthma : official journal of the Association for the Care of Asthma. 2011;48(8):767-72.

82. Bara I, Ozier A, Girodet PO, Carvalho G, Cattiaux J, Begueret H, et al. Role of YKL-40 in bronchial smooth muscle remodeling in asthma. American journal of respiratory and critical care medicine. 2012;185(7):715-22.

83. Letuve S, Kozhich A, Arouche N, Grandsaigne M, Reed J, Dombret MC, et al. YKL-40 is elevated in patients with chronic obstructive pulmonary disease and activates alveolar macrophages. J Immunol. 2008;181(7):5167-73.

84. Batinic K, Hobaus C, Grujicic M, Steffan A, Jelic F, Lorant D, et al. YKL-40 is elevated in patients with peripheral arterial disease and diabetes or pre-diabetes. Atherosclerosis. 2012;222(2):557-63.

85. Sakamoto F, Katakami N, Kaneto H, Yasuda T, Takahara M, Miyashita K, et al. Association of serum YKL-40 levels with urinary albumin excretion rate in young Japanese patients with type 1 diabetes mellitus. Endocr J. 2012;15:15.

86. Pei D. Leukolysin/MMP25/MT6-MMP: a novel matrix metalloproteinase specifically expressed in the leukocyte lineage. Cell Res. 1999;9(4):291-303.

87. Kang $T$, Yi J, Guo A, Wang X, Overall CM, Jiang W, et al. Subcellular distribution and cytokine- and chemokine-regulated secretion of leukolysin/MT6-MMP/MMP-25 in neutrophils. J Biol Chem. 2001;276(24):21960-8.

88. Blumenthal MN, Zhong W, Miller M, Wendt C, Connett JE, Pei D. Serum metalloproteinase leukolysin (MMP-25/MT-6): a potential metabolic marker for atopy-associated inflammation. Clinical and experimental allergy : journal of the British Society for Allergy and Clinical Immunology. 2010;40(6):859-66.

89. Kunkel SL, Standiford T, Kasahara K, Strieter RM. Interleukin-8 (IL-8): the major neutrophil chemotactic factor in the lung. Exp Lung Res. 1991;17(1):17-23.

90. Shute JK, Vrugt B, Lindley IJ, Holgate ST, Bron A, Aalbers R, et al. Free and complexed interleukin-8 in blood and bronchial mucosa in asthma. American journal of respiratory and critical care medicine. 1997;155(6):1877-83.

91. Hollander C, Sitkauskiene B, Sakalauskas R, Westin U, Janciauskiene SM. Serum and bronchial lavage fluid concentrations of IL-8, SLPI, SCD14 and sICAM-1 in patients with COPD and asthma. Respir Med. 2007;101(9):1947-53.

92. Yokoyama A, Kohno N, Sakai K, Kondo K, Hirasawa Y, Hiwada K. Circulating levels of soluble interleukin- 6 receptor in patients with bronchial asthma. American journal of respiratory and critical care medicine. 1997;156(5):1688-91. 
93. Tato CM, O'Shea JJ. Immunology: what does it mean to be just 17?: Nature. 2006 May $11 ; 441(7090): 166-8$.

94. Donaldson GC, Seemungal TA, Patel IS, Bhowmik A, Wilkinson TM, Hurst JR, et al. Airway and systemic inflammation and decline in lung function in patients with COPD. Chest. 2005;128(4):1995-2004.

95. Cazzola M, Matera MG. IL-17 in chronic obstructive pulmonary disease: Expert Rev Respir Med. 2012 Apr;6(2):135-8.

96. Huang HJ, Lin YL, Liu CF, Kao HF, Wang JY. Mite allergen decreases DC-SIGN expression and modulates human dendritic cell differentiation and function in allergic asthma. Mucosal Immunol. 2011;4(5):519-27.

97. Vizmanos-Lamotte G, Moreno-Galdo A, Munoz X, Gomez-Olles S, Gartner S, Cruz MJ. Induced sputum cell count and cytokine profile in atopic and non-atopic children with asthma. Pediatric pulmonology. 2013;8(10):22769.

98. Tsai TC, Lu JH, Chen SJ, Tang RB. Soluble interleukin-10 and transforming growth factorbeta in children with acute exacerbation of allergic asthma. The Journal of asthma : official journal of the Association for the Care of Asthma. 2009;46(1):21-4.

99. Yalcin AD, Bisgin A, Gorczynski RM. IL-8, IL-10, TGF-beta, and GCSF levels were increased in severe persistent allergic asthma patients with the anti-lgE treatment. Mediators Inflamm. 2012;720976(10):19.

100. Zieg G, Lack G, Harbeck RJ, Gelfand EW, Leung DY. In vivo effects of glucocorticoids on IgE production. The Journal of allergy and clinical immunology. 1994;94(2 Pt 1):222-30.

101. Vijverberg SJ, Koenderman L, Koster ES, van der Ent CK, Raaijmakers JA, Maitland-van der Zee AH. Biomarkers of therapy responsiveness in asthma: pitfalls and promises. Clinical and experimental allergy : journal of the British Society for Allergy and Clinical Immunology. 2011;41(5):615-29.

102. Strachan D, Sibbald B, Weiland S, Ait-Khaled N, Anabwani G, Anderson HR, et al. Worldwide variations in prevalence of symptoms of allergic rhinoconjunctivitis in children: the International Study of Asthma and Allergies in Childhood (ISAAC). Pediatr Allergy Immunol. 1997;8(4):161-76.

103. Position paper: Allergen standardization and skin tests. The European Academy of Allergology and Clinical Immunology. Allergy. 1993;48(14 Suppl):48-82.

104. Hirose H, Matsuse H, Tsuchida T, Fukahori S, Fukushima C, Mizuta Y, et al. Cytokine production from peripheral blood mononuclear cells of mite allergen-sensitized atopic adults stimulated with respiratory syncytial virus and mite allergen. Int Arch Allergy Immunol. 2008;146(2):149-55.

105. Dabitao D, Margolick JB, Lopez J, Bream JH. Multiplex measurement of proinflammatory cytokines in human serum: comparison of the Meso Scale Discovery electrochemiluminescence assay and the Cytometric Bead Array. J Immunol Methods. 2011;372(1-2):71-7.

106. Cuhadar S, Koseoglu M, Atay A, Dirican A. The effect of storage time and freeze-thaw cycles on the stability of serum samples. Biochem Med. 2013;23(1):70-7. 
Serum Biomarkers in Elderly Asthma 


\section{Attachments}

Table 3 - Summary of studies evaluating serum biomarkers of asthma.

\begin{tabular}{|c|c|c|c|}
\hline Markers & Study & Population (mean age) & Outcome \\
\hline \multirow{3}{*}{ IgE (total) } & $(49)^{1}$ & $\begin{array}{c}86 \text { patients with asthma (38.0); } 36 \text { with COPD (56.8); } 13 \text { with partial } \\
\text { reversibility }(57.9) ; 75 \mathrm{HC}(42.3) .\end{array}$ & \multirow{3}{*}{$\begin{array}{l}\text { Large overlapping of serum total lgE was observed in both allergic and } \\
\text { HC populations. Good sensibility, poor specificity and poor negative } \\
\text { predictive value. }\end{array}$} \\
\hline & $(56)^{1}$ & 33 elderly asthmatics (65-90); 21 elderly HC (65-90). & \\
\hline & $(50)^{2}$ & 771 asthmatics (7.8 and 30.1); $117 \mathrm{HC}$ (6.6 and 30.7). & \\
\hline $\begin{array}{c}\text { lgE } \\
\text { (specific) }\end{array}$ & $(56)^{1}$ & 33 elderly asthmatics (65-90); 21 elderly HC (65-90). & IgE for DerP was higher in asthmatic than in non-asthmatic patients. \\
\hline \multirow[t]{2}{*}{ CRP } & $(59)^{3}$ & $\begin{array}{l}96 \text { patients with asthma exacerbations (18-84); } 62 \text { with pneumonia (24-93); } \\
\qquad 161 \text { with COPD exacerbations (39-93). }\end{array}$ & \multirow[t]{2}{*}{$\begin{array}{l}\text { No significant difference between CRP levels in COPD, asthma } \\
\text { exacerbations and HC. }\end{array}$} \\
\hline & $(58)^{1}$ & 50 patients with rhinitis (32); 20 asthmatics (36); $20 \mathrm{HC}(31)$. & \\
\hline \multirow{2}{*}{ Hs-CRP } & $(60)^{1}$ & $\begin{array}{c}26 \text { asthmatics treated with ICS (33.3); } 24 \text { ICS naive (35.1); } 15 \mathrm{HC} \text { (matching } \\
\text { age). }\end{array}$ & $\begin{array}{l}\text { Hs-CRP was significantly increased in asthmatic patients, compared to } \\
\qquad \mathrm{HC} \text {, even under ICS treatment. }\end{array}$ \\
\hline & $(7)^{1}$ & 106 NNA (57.4); 26 NA (62.6); 83 HC (61.3) & Hs-CRP levels were not elevated in NNA. Hs-CRP increased in NA. \\
\hline
\end{tabular}




\begin{tabular}{|c|c|c|c|}
\hline Markers & Study & Population (mean age) & Outcome \\
\hline Hs-CRP & $(49)^{1}$ & $\begin{array}{c}86 \text { patients with asthma }(38.0) ; 36 \text { with COPD }(56.8) ; 13 \text { with partial } \\
\text { reversibility }(57.9) ; 75 \mathrm{HC}(42.3) \text {. }\end{array}$ & $\begin{array}{l}\text { Hs-CRP was significantly increased in patients with COPD, compared } \\
\text { to asthmatics and HC. }\end{array}$ \\
\hline Neopterin & $(75)^{1}$ & 42 allergic asthmatics and 22 non-allergic asthmatics (72.4); $41 \mathrm{HC}(79.2)$. & $\begin{array}{l}\text { Neopterin was increased in non-allergic asthmatics in comparison } \\
\text { with allergic asthmatics and HC. }\end{array}$ \\
\hline \multirow{2}{*}{ SAA } & $(58)^{1}$ & 50 patients with rhinitis (32); 20 asthmatics (36); $20 \mathrm{HC}(31)$. & \multirow{2}{*}{$\begin{array}{l}\text { Patients with asthma showed significantly higher SSA levels compared } \\
\text { to HC. }\end{array}$} \\
\hline & $(65)^{3}$ & 17 asthmatics BT (35.5); 10 asthmatics AT (30.0); $10 \mathrm{HC}$ (31.0). & \\
\hline \multirow{3}{*}{ ECP } & $(64)^{1}$ & 441 patients with RD (57.0); $33 \mathrm{HC}(63.0)$. & $\begin{array}{c}\text { ECP was significantly higher in patients with RD compared to healthy } \\
\text { volunteers. No correlation was found between serum ECP value and } \\
\text { PBE absolute number. The predictive model was significant only for } \\
\text { asthma, with a sensitivity of } 70 \% \text { and a specificity of } 74 \% \text { (efficiency } \\
73 \% \text { ). }\end{array}$ \\
\hline & $(56)^{1}$ & 33 elderly asthmatics (65-90); 21 elderly HC (65-90). & $\begin{array}{l}\text { ECP levels were not significantly different between elderly asthmatic } \\
\text { and HC. }\end{array}$ \\
\hline & $(65)^{3}$ & 17 asthmatics BT (35.5); 10 asthmatics AT (30.0); $10 \mathrm{HC}(31.0)$. & $\begin{array}{l}\text { ECP was significantly increased in asthmatics BT compared to HC and } \\
\text { asthmatics AT. }\end{array}$ \\
\hline UTI & $(61)^{1}$ & 25 asthmatic children (3.4); $15 \mathrm{HC}$ (3.5). & $\begin{array}{l}\text { Children with asthma exacerbations had significantly higher levels of } \\
\text { serum UTI compared to HC of the same age. }\end{array}$ \\
\hline
\end{tabular}




\begin{tabular}{|c|c|c|c|}
\hline Markers & Study & Population (mean age) & Outcome \\
\hline Leukolysin & $(88)^{1}$ & $\begin{array}{l}337 \text { patients from nuclear families with asthma (28.1); } 122 \text { “married-in” } \\
\text { individuals (48.8). }\end{array}$ & $\begin{array}{l}\text { Changes in serum leukolysin were closely paralleled to those of total } \\
\qquad \operatorname{lgE} \text { in both atopic asthmatics and COPD. }\end{array}$ \\
\hline \multirow{4}{*}{ YKL-40 } & $(81)^{1}$ & 59 asthmatics (23-76); 29 HC (20-80). & $\begin{array}{l}\text { YKL-40 was significantly increased in asthmatics compared to HC. No } \\
\text { relations were found between YKL-40 level and asthma severity, } \\
\text { control, or total serum IgE. }\end{array}$ \\
\hline & $(79)^{1}$ & $\begin{array}{l}\text { Three cohorts with a total of } 194 \text { patients with asthma (44.0) and a total of } \\
\qquad 59 \mathrm{HC}(42.0)\end{array}$ & \multirow{2}{*}{$\begin{array}{l}\text { YKL- } 40 \text { was significantly increased in asthmatics compared to } \mathrm{HC} \text {. } \\
\text { Serum YKL- } 40 \text { correlated positively with total serum IgE and PBE. }\end{array}$} \\
\hline & $(80)^{4}$ & $\begin{array}{l}16 \text { patients with stable asthma (30.9); } 46 \text { with asthma exacerbations (43.3); } \\
64 \mathrm{HC}(42.2) .\end{array}$ & \\
\hline & $(82)^{3}$ & 40 asthmatics (47.0); 13 non-smokers (50.0); 16 smokers (55.0). & $\begin{array}{l}\text { Serum YKL-40 was significantly increased in asthmatics compared to } \\
\text { controls, and correlated with bronchial smooth muscle cells } \\
\text { migration. }\end{array}$ \\
\hline sCD86 & $(71)^{1}$ & $\begin{array}{l}24 \text { patients with stable asthma (39.2); } 28 \text { with aggravated asthma (42.2); } 25 \\
\text { HC (38.1). }\end{array}$ & $\begin{array}{l}\text { sCD86 was significantly increased in acute asthmatics compared to } \\
\text { stable and HC. No significant differences were found between CD86 } \\
\text { levels in stable asthmatics and HC. }\end{array}$ \\
\hline
\end{tabular}

Type of study: ${ }^{1}$ Cross-sectional; ${ }^{2}$ Retrospective; ${ }^{3}$ Prospective; ${ }^{4}$ Case-control. Abbreviations: HC=Healthy Controls; BT=Before Treatment; AT=After Treatment; $\mathrm{NA}=$ Neutrophilic Asthmatics; NNA=Non-neutrophilic asthmatics; PBE=Peripheral Blood Eosinophils; ICS=Immunocorticosteroids; RD=Respiratory Diseases. 
Table 4 - Summary of studies evaluating serum cytokines as markers of asthma.

\begin{tabular}{|c|c|c|c|}
\hline Markers & Study & Population (mean age) & Outcome \\
\hline IL-6 & $(7)^{1}$ & 106 NNA (57.4); 26 NA (62.6); 83 HC (61.3). & $\begin{array}{l}\text { IL-6 levels were significantly increased in both asthmatic groups when compared to HC, and } \\
\text { were significantly increased in NA when compared to NNA. }\end{array}$ \\
\hline \multirow{3}{*}{ IL-8 } & $(7)^{1}$ & 106 NNA (57.4); 26 NA (62.6); 83 HC (61.3). & IL-8 was significantly increased in NA when compared to NNA and HC. \\
\hline & $(8)^{1}$ & $\begin{array}{l}22 \text { mild/moderate asthmatics }(44.5) ; 14 \text { severe } \\
\text { asthmatics }(56.6) ; 20 \mathrm{HC}(43.4) .\end{array}$ & $\begin{array}{l}\text { IL-8 levels were significantly higher in both asthmatic groups, and in severe asthmatics IL-8 } \\
\text { levels were significantly higher than in mild/moderate asthmatics. Severe asthmatics were } \\
\text { significantly older. }\end{array}$ \\
\hline & $(91)^{1}$ & 13 asthmatics (54.3); 25 with COPD (64.0). & No significant differences were found between serum IL-8 levels of asthma and COPD. \\
\hline \multirow[b]{2}{*}{ IL-10 } & $(98)^{1}$ & $\begin{array}{l}22 \text { allergic asthmatic children (8.6); } 16 \mathrm{HC} \text { of matching } \\
\text { age. }\end{array}$ & No significant differences in circulating IL-10 levels were found between the two groups. \\
\hline & $(99)^{1}$ & $\begin{array}{l}14 \text { patients with severe allergic asthma (18-62); } 14 \\
\text { patients with controlled allergic asthma (20-62); } 14 \mathrm{HC} \\
(19-61) .\end{array}$ & $\begin{array}{l}\text { IL-10 circulating levels are significantly lower in asthmatics before anti-lgE treatment, when } \\
\text { compared to the post-treated patients. }\end{array}$ \\
\hline IL-12p70 & $(97)^{1}$ & $\begin{array}{l}60 \text { allergic asthmatic children; } 17 \text { non-allergic } \\
\text { asthmatic children; } 31 \mathrm{HC} \text {; all aged } 7 \text { to } 15 \text { years old. }\end{array}$ & $\begin{array}{l}\text { IL-12p70 was significantly increased in the allergic asthmatic group when compared to the } \\
\text { non-allergic asthmatic group. }\end{array}$ \\
\hline IL-17 & $(15)^{1}$ & $\begin{array}{l}23 \text { patients with mild asthma (41.4); } 26 \text { with moderate } \\
\text { asthma (46.6); } 36 \text { with severe asthma (50.8). }\end{array}$ & $\begin{array}{l}\text { Patients with severe asthma were significantly older than patients with mild asthma. IL-17 } \\
\text { was significantly increased in severe asthma compared to mild/moderate forms. }\end{array}$ \\
\hline \multirow{3}{*}{ TNF-a } & $(7)^{1}$ & 106 NNA (57.4); 26 NA (62.6); 83 HC (61.3) & TNF- $a$ showed no significant differences between NA, NNA and HC. \\
\hline & $(8)^{1}$ & $\begin{array}{l}22 \text { mild/moderate asthmatics }(44.5) ; 14 \text { severe } \\
\text { asthmatics }(56.6) ; 20 \mathrm{HC}(43.4) \text {. }\end{array}$ & \multirow{2}{*}{ TNF- $a$ was significantly increased in severe asthmatics compared to other asthmatics and HC. } \\
\hline & $(15)^{1}$ & $\begin{array}{l}23 \text { patients with mild asthma (41.4); } 26 \text { with moderate } \\
\text { asthma (46.6); } 36 \text { with severe asthma (50.8). }\end{array}$ & \\
\hline
\end{tabular}

Type of study: ${ }^{1}$ Cross-sectional; ${ }^{2}$ Retrospective; ${ }^{3}$ Prospective; ${ }^{4}$ Case-control. Abbreviations: HC=Healthy Controls; BT=Before Treatment; AT=After Treatment; NA=Neutrophilic Asthmatics; NNA=Non-neutrophilic asthmatics; PBE=Peripheral Blood Eosinophils; ICS=Immunocorticosteroids; RD=Respiratory Diseases. 


\section{CBA Calibration Curves}

\section{IL-12p70}

Table 5 - Fluorescence values for standard concentrations of IL-12p70. MFI values at $625 \mathrm{pg} / \mathrm{ml}$ were out of the normal range of the curve.

\begin{tabular}{ccc}
\hline Standards & $\begin{array}{c}\text { IL-12p70 } \\
\text { Concentration } \\
(\mathrm{pg} / \mathrm{ml})(\mathrm{x})\end{array}$ & $\begin{array}{c}\mathrm{FL2} \text { MFI } \\
(\mathrm{y})\end{array}$ \\
\hline 1 & 0,00 & 5,67 \\
2 & 20,00 & 12,50 \\
3 & 40,00 & 17,90 \\
4 & 80,00 & 30,40 \\
5 & 156,00 & 47,80 \\
6 & 312,00 & 80,20 \\
7 & 625,00 & $\mathrm{NA}$ \\
\hline
\end{tabular}

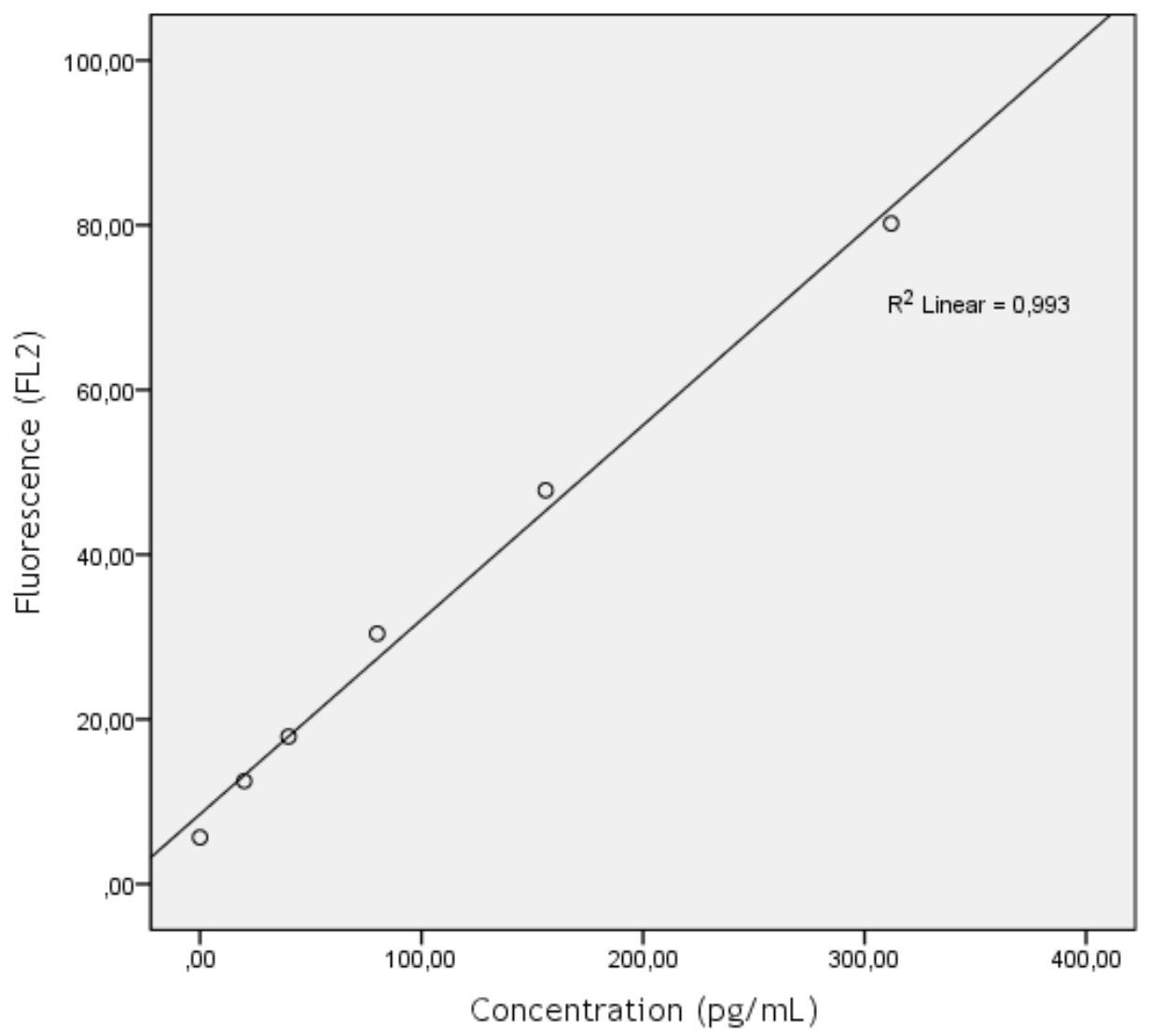

Figure 8 - Calibration curve for IL-12p70. 


\section{TNF-a}

Table 6 - Fluorescence values for standard concentrations of TNF-a.

\begin{tabular}{|c|c|c|}
\hline \multicolumn{3}{|c|}{ TNF- $\alpha$} \\
\hline Standards & $\begin{array}{c}\text { Concentration } \\
(\mathrm{pg} / \mathrm{ml})(\mathrm{x})\end{array}$ & $\begin{array}{c}\text { FL2 MFI } \\
(y)\end{array}$ \\
\hline 1 & 0,00 & 4,40 \\
\hline 2 & 20,00 & 7,70 \\
\hline 3 & 40,00 & 10,00 \\
\hline 4 & 80,00 & 16,30 \\
\hline 5 & 156,00 & 21,20 \\
\hline 6 & 312,00 & 53,80 \\
\hline 7 & 625,00 & 110,90 \\
\hline
\end{tabular}

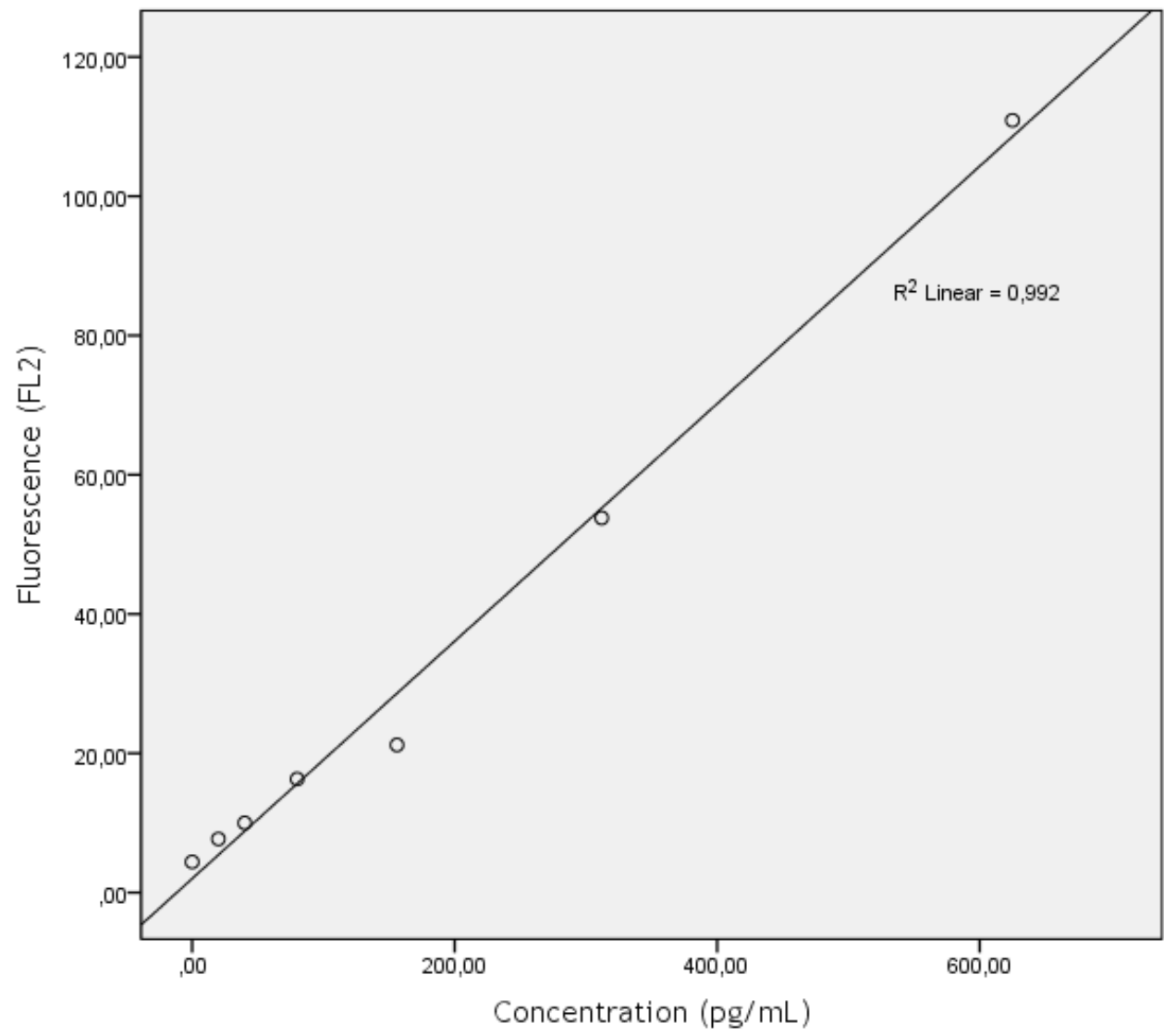

Figure 9 - Calibration curve for TNF-a. 
IL-10

Table 7 - Fluorescence values for standard concentrations of IL-10.

\begin{tabular}{|c|c|c|}
\hline \multicolumn{3}{|c|}{ IL-10 } \\
\hline Standards & $\begin{array}{l}\text { Concentration } \\
(\mathrm{pg} / \mathrm{ml})(\mathrm{x})\end{array}$ & $\begin{array}{c}\text { FL2 MFI } \\
(y)\end{array}$ \\
\hline 1 & 0,00 & 3,40 \\
\hline 2 & 20,00 & 16,30 \\
\hline 3 & 40,00 & 25,00 \\
\hline 4 & 80,00 & 45,70 \\
\hline 5 & 156,00 & 71,70 \\
\hline 6 & 312,00 & 145,90 \\
\hline 7 & 625,00 & 316,20 \\
\hline
\end{tabular}

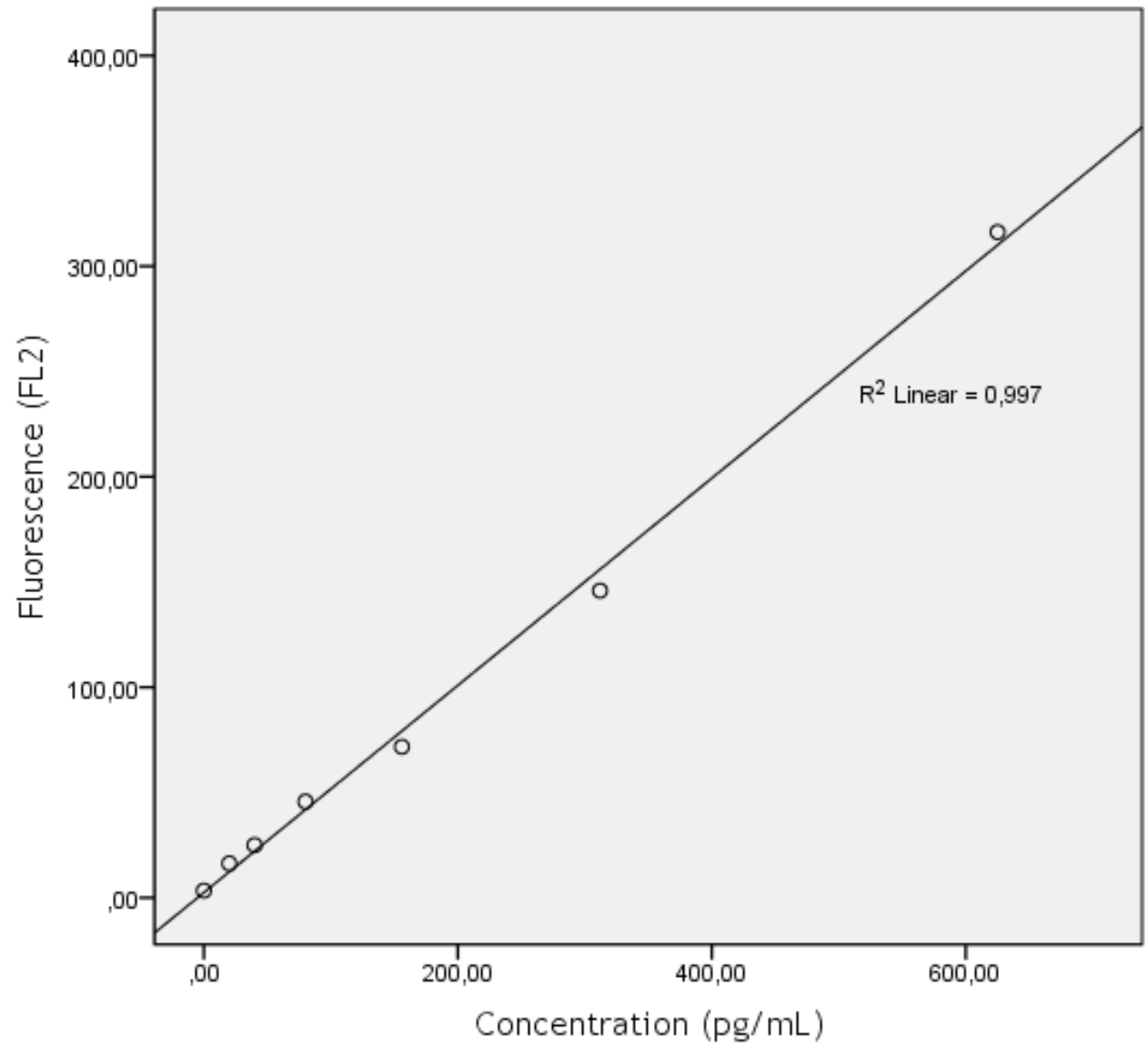

Figure 10 - Calibration curve for IL-10. 
IL-6

Table 8 - Fluorescence values for standard concentrations of IL-6

\begin{tabular}{ccc}
\hline IL-6 \\
Standards & $\begin{array}{c}\text { Concentration } \\
(\mathrm{pg} / \mathrm{ml})(\mathrm{x})\end{array}$ & $\begin{array}{c}\text { FL2 MFI } \\
(\mathrm{y})\end{array}$ \\
\hline 1 & 0,00 & 5,60 \\
2 & 20,00 & 16,50 \\
3 & 40,00 & 23,90 \\
4 & 80,00 & 41,00 \\
5 & 156,00 & 56,50 \\
6 & 312,00 & 137,60 \\
7 & 625,00 & 289,00 \\
\hline
\end{tabular}

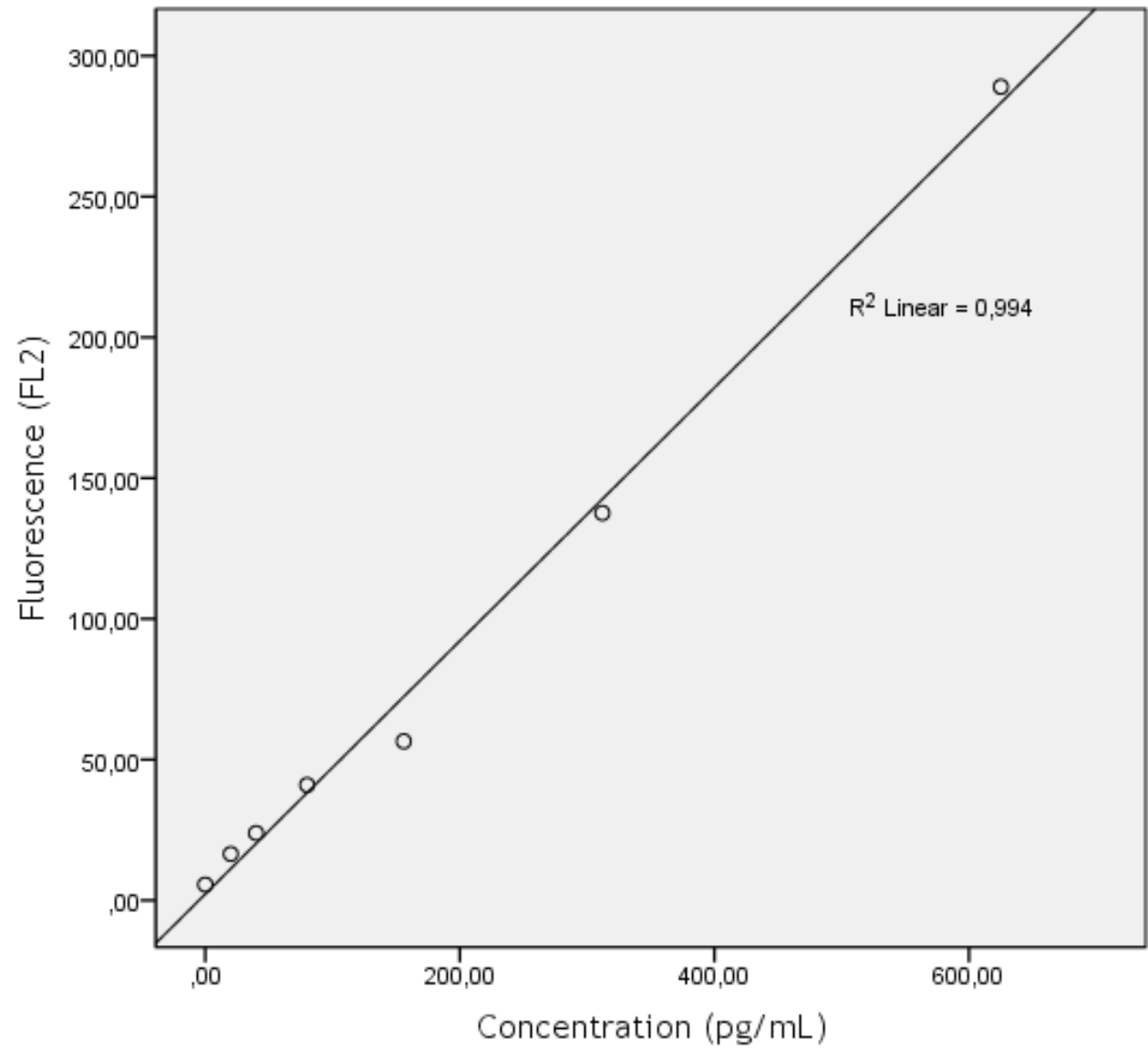

Figure 11 - Calibration curve for IL-10. 
IL-1B

Table 9 - Fluorescence values for standard concentrations of IL-1B.

\begin{tabular}{|c|c|c|}
\hline \multicolumn{3}{|c|}{ IL-1B } \\
\hline Standards & $\begin{array}{l}\text { Concentration } \\
(\mathrm{pg} / \mathrm{ml})(\mathrm{x})\end{array}$ & $\begin{array}{c}\text { FL2 MFI } \\
(y)\end{array}$ \\
\hline 1 & 0,00 & 5,40 \\
\hline 2 & 20,00 & 15,30 \\
\hline 3 & 40,00 & 21,90 \\
\hline 4 & 80,00 & 39,20 \\
\hline 5 & 156,00 & 55,50 \\
\hline 6 & 312,00 & 129,80 \\
\hline 7 & 625,00 & 286,40 \\
\hline
\end{tabular}

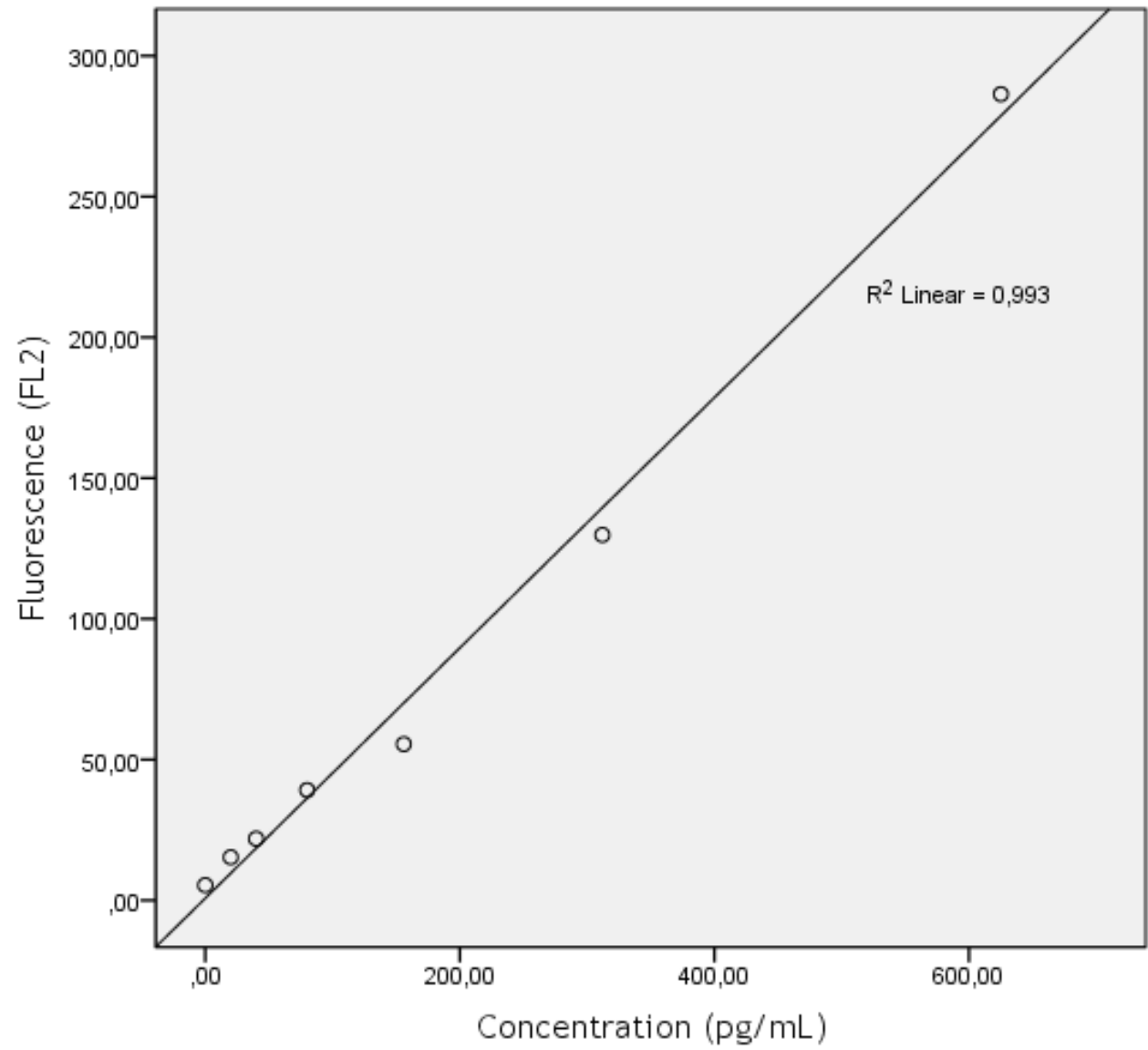

Figure 12 - Calibration curve for IL-1B. 
IL-8

Table 10 - Fluorescence values for standard concentrations of IL-8.

\begin{tabular}{|c|c|c|}
\hline \multicolumn{3}{|c|}{ IL-8 } \\
\hline Standards & $\begin{array}{l}\text { Concentration } \\
(\mathrm{pg} / \mathrm{ml})(\mathrm{x})\end{array}$ & $\begin{array}{c}\text { FL2 MFI } \\
(y)\end{array}$ \\
\hline 1 & 0,00 & 4,60 \\
\hline 2 & 20,00 & 14,10 \\
\hline 3 & 40,00 & 19,60 \\
\hline 4 & 80,00 & 33,40 \\
\hline 5 & 156,00 & 57,30 \\
\hline 6 & 312,00 & 93,10 \\
\hline 7 & 625,00 & 203,50 \\
\hline
\end{tabular}

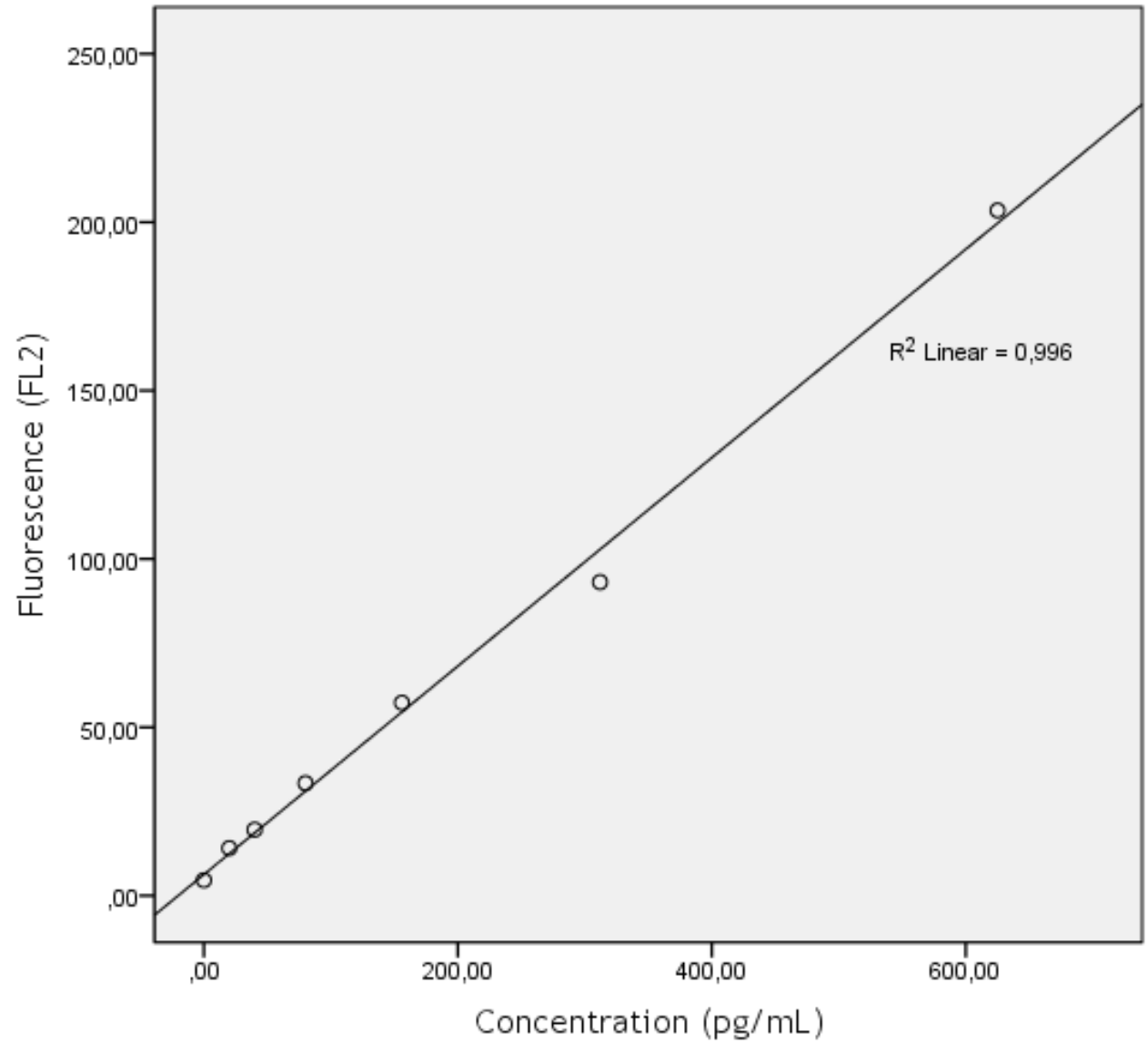

Figure 13 - Calibration curve for IL-8. 